\title{
Transactions
}

Cite this: Dalton Trans., 2011, 40, 1471

wWW.rsc.org/dalton

PAPER

\section{Novel N-heterocyclic ylideneamine gold(I) complexes: synthesis, characterisation and screening for antitumour and antimalarial activity $\dagger$}

\author{
Jacorien Coetzee, ${ }^{a}$ Stephanie Cronje, ${ }^{* a}$ Liliana Dobrzańska, ${ }^{a}$ Helgard G. Raubenheimer, ${ }^{a}$ Gisela Jooné ${ }^{b}$ \\ Margo J. Nell ${ }^{b}$ and Heinrich C. Hoppe ${ }^{c}$
}

Received 30th September 2010, Accepted 18th November 2010

DOI: $10.1039 / \mathbf{c o d t 0 1 3 1 2 a}$

Ylideneamine functionalised heterocyclic ligands, 1,3-dimethyl-1,3-dihydro-benzimidazol-2-
ylideneamine (I), 3-methyl-3H-benzothiazol-2-ylideneamine (II) or 3,4-dimethyl-3H-thiazol-2-
ylideneamine (III), were employed in the preparation of a series of both charged and neutral gold(I)
complexes consisting either of a $\mathrm{Au}\left(\mathrm{C}_{6} \mathrm{~F}_{5}\right)$ fragment $(\mathbf{1 - 3})$, a $\left[\mathrm{Au}\left(\mathrm{PPh}_{3}\right)\right]^{+}$unit $(\mathbf{4 - 6})$ or a
$[\mathrm{Au}(\mathrm{NHC})]^{+}$unit $(\mathbf{7})$ coordinated to the imine nitrogen of the neutral ylideneamine ligand. These
complexes were fully characterised by various techniques including X-ray diffraction. In addition, the
antitumour and antimalarial potential of selected compounds were assessed in a preliminary study
aimed at determining the medicinal value of such compounds. Complexation of the
azol-2-ylideneamine ligands with $\left[\mathrm{Au}\left(\mathrm{PPh}_{3}\right)\right]^{+}$increases their antitumour as well as antimalarial activity.

\section{Introduction}

The coordination chemistry of phosphazenido ligands of the general type $\left[\mathrm{R}_{3} \mathrm{P}=\mathrm{N}\right]^{-}$has been studied extensively over the past few decades leading to the discovery of a vast number of structurally diverse main group and transition metal complexes. ${ }^{1}$ Neutral phosphazene ligands, $\mathrm{R}_{3} \mathrm{P}=\mathrm{NH}$, can be readily prepared by the acid catalysed reactions of $\mathrm{N}$-silylized phosphazenes $\mathrm{R}_{3} \mathrm{P}=\mathrm{NSiMe}_{3}$, with $i$-propanol or methanol, or by deprotonation of the corresponding aminophosphonium salts, $\left[\mathrm{R}_{3} \mathrm{P}=\mathrm{NH}_{2}\right] \mathrm{Cl}$ using sodium amide. These ligands are, however, thermally sensitive and prone to oxidation in the presence of water affording related phosphorane oxides. ${ }^{2}$ Efforts to improve the stability of this class of compounds have led to the discovery of the related imidazol-2ylideneamine and thiazol-2-ylideneamine analogues. Replacement of the $\mathrm{PR}_{3}$ moiety in phosphazenes with an $\mathrm{N}$-heterocyclic carbene (NHC) was an initiative that exploited the striking electronic similarities between the electron rich trialkylphosphines and NHC's. ${ }^{3}$ In contrast to the phosphazenes, their ylideneamine counterparts are less susceptible to oxidation and may be regarded as superior in terms of stability.

${ }^{a}$ Department of Chemistry and Polymer Science, University of Stellenbosch, Private Bag X1, Matieland, 7602, Stellenbosch, South Africa. E-mail: scron@sun.ac.za, stephanie.cronje@gmail.com; Fax: +27 21808 3849; Tel: +27218082180

${ }^{b}$ Department of Pharmacology, Faculty of Medicine, University of Pretoria, P.O. Box 2034, Pretoria, 0001, South Africa

'CSIR, Biosciences, P.O. Box 395, Pretoria, 0001, South Africa

$\dagger$ Electronic supplementary information (ESI) available: Synthesis of IV and crystallographic data of 4a. CCDC reference numbers 801423-801432. For ESI and crystallographic data in CIF or other electronic format see DOI: $10.1039 / \mathrm{c} 0 \mathrm{dt} 01312 \mathrm{a}$
Since their discovery, ylideneamines and their transition metal complexes have attracted considerable interest owing to their biological activity. Metformin (1,1-dimethylbiguanide) derivatives, in particular, are well known for their medicinal value. These compounds show significant versatility in their biological activity and have been employed as therapeutic agents for the treatment of pain, anxiety, memory disorders, diabetes and malaria. ${ }^{4}$ Similarly, benzimidazol-2-ylamine and benzimidazol-2ylideneamine derivatives have been utilised in the formulation of treatments for severe illnesses such as Parkinson's disease, multiple sclerosis, neurological disorders and strokes. ${ }^{5}$ Moreover, molecules containing a core 2-aminobenzothiazole scaffold have been found to reduce parasitaemia (Plasmodium falciparum) by $80 \%$ at a concentration of $10 \mu \mathrm{M} .{ }^{6}$ The $\mathrm{N}-\mathrm{H}$ functionality in ylideneamine ligands appears to play a fundamental role in their biological activity, and is believed to participate in the formation of hydrogen bonds to biomolecules. It is a functionality that could even be considered as essential for anticancer activity. ${ }^{7}$

Despite extensive reports on the biological activity of ylideneamine derivatives and metal complexes thereof, the literature provides very little information regarding their antitumour activity. On the other hand, gold(I) phosphine complexes are renowned for showing potential as antitumour agents. ${ }^{8}$ Additionally, the chloroquine complex of triphenylphosphinegold(I) was found to be active against two strains of malaria. Against Plasmodium falciparum, in particular, this complex proved 4-9 times more active than chloroquinediphosphate and other metal complex candidates. ${ }^{9}$ In bi-coordinate linear gold(I) phosphine complexes, the antitumour activity and cytotoxicity are modulated not only by the phosphine substituents but also by the nature of the auxiliary ligands present. Complexes with good leaving groups positioned trans to the phosphine display reduced antitumour 
activity. This arises from the reactivity of such complexes towards thiols, enabling the formation of strong protein bonds to $\mathrm{AuPR}_{3}$, which in turn prevents gold(I) phosphines from reaching their intracellular targets. ${ }^{10}$

Preliminary studies by Baker and co-workers ${ }^{11}$ have shown that several dinuclear gold(I) complexes containing bridging NHC ligands induce membrane permeabilisation in rat liver mitochondria. This suggests that NHC-containing gold(I) complexes may be considered as promising alternatives to phosphine complexes in the development of chemotherapeutic agents.

Notwithstanding the variety of existing pentafluorophenyl (pfp), phosphine and NHC gold(I) complexes, the few such compounds known to also contain ylideneamine ligands are limited to simple ketimine or guanidine types. ${ }^{12}$ Inspired by this scarcity together with the biological activity displayed by ylideneamine metal complexes, we now report on the preparation and extensive characterisation of a series of pfp-, phosphine- and NHC-containing ylideneamine gold(I) complexes. In addition, to evaluate whether a possible synergism could be detected between the different combinations of coordinating functionalities, a number of these complexes were assessed for their potential as anticancer and antimalarial agents. The preliminary outcome of these assays is described in this account.

\section{Results and discussion}

\section{Ylideneamine-functionalised heterocyclic carbene complexes}

The most general route towards the preparation of ylideneaminefunctionalised heterocyclic carbenes was developed by Kuhn and co-workers. ${ }^{13}$ Their method entails alkylation of the endocyclic nitrogen atom of a 1-methyl-1 $H$-imidazol-2-ylamine derivative with MeI to yield a cationic amino compound. The latter can then be readily converted to the corresponding ylideneamine by deprotonation with potassium hydride. A similar approach was followed in the preparation of ligands I-III from the appropriate amino precursors, with the only variation being the choice of alkylating agent (Scheme 1).

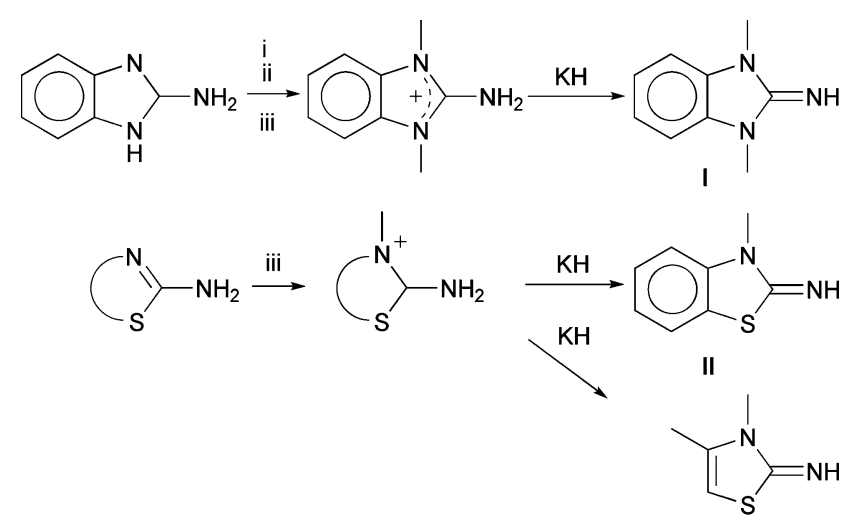

III

Scheme 1 Preparation of ylideneamine-functionalised heterocyclic carbenes $\mathbf{I}-\mathbf{I I I}$; i $=\mathrm{KOH}$, ii $=\mathrm{MeI}$ and $\mathrm{iii}=\mathrm{CF}_{3} \mathrm{SO}_{3} \mathrm{Me}$.

In the case of $\mathbf{I}$, where multiple alkylations were required, the initial alkylation could be achieved by deprotonation of the endocyclic $\mathrm{N}$-atom with $\mathrm{KOH}$, followed by treatment with
MeI. Alkylation of the resulting neutral product with $\mathrm{CF}_{3} \mathrm{SO}_{3} \mathrm{Me}$ and subsequent deprotonation with $\mathrm{KH}$ (as for II and III) gave the neutral ligand $\mathbf{I}$ in good yield. Strict temperature control during the execution of the final deprotonation step proved crucial in all instances. Reaction temperatures above $66{ }^{\circ} \mathrm{C}$ led to the formation of dimeric byproducts, especially when preparing the thiazole derivatives II and III. X-ray structure elucidation of a single crystal isolated from a crystallisation mixture of II aided in identifying the byproduct as 3-methyl-2-(3methyl-3H-benzothiazol-2-ylideneamino)benzothiazol-3-ium trifluoromethanesulfonate $(\mathbf{I V} \dagger)$, the result of a condensation reaction which entails the loss of ammonia. Compounds similar to this dimeric byproduct have been prepared by Deligeorgiev and Gadjev $^{14}$ by treating 3-methyl-3H-benzothiazol-2-ylideneamine derivatives with $\mathrm{HX}$, where $\mathrm{X}=\mathrm{CH}_{3} \mathrm{SO}_{3}^{-}, \mathrm{ClO}_{4}^{-}, \mathrm{Br}^{-}$or $\mathrm{I}^{-}$.

The highly hygroscopic ligands $\mathbf{I}-\mathbf{I I I}$ are soluble in water and organic solvents such as alcohols, dichloromethane, DMSO, THF, acetone or diethyl ether, but insoluble in alkanes such as $n$-pentane and $n$-hexane.

\section{Pentafluorophenyl gold(I) complexes}

We have recently again emphasised the value of $\left[\mathrm{Au}\left(\mathrm{C}_{6} \mathrm{~F}_{5}\right)(\mathrm{tht})\right]$ (tht $=$ tetrahydrothiophene) as a gold(I) precursor complex, which freely allows the substitution of the tht ligand by ligands with superior donor abilities. ${ }^{15,16}$ Ylideneamine ligands are considered to be strong $\sigma$-donors and therefore readily replace tht to form neutral coordination complexes of the general form $\left[\mathrm{Au}\left(\mathrm{C}_{6} \mathrm{~F}_{5}\right)(\mathrm{L})\right]$, where $\mathrm{L}$ refers to the ylideneamine ligand. Scheme 2 depicts the facile preparation of neutral ylideneamine-coordinated (pfp)gold(I) complexes 1-3. These air and moisture sensitive compounds were prepared in moderate to high yields by treating solutions of ligands I-III in THF with equimolar amounts of $\left[\mathrm{Au}\left(\mathrm{C}_{6} \mathrm{~F}_{5}\right)(\mathrm{tht})\right]$ at room temperature.

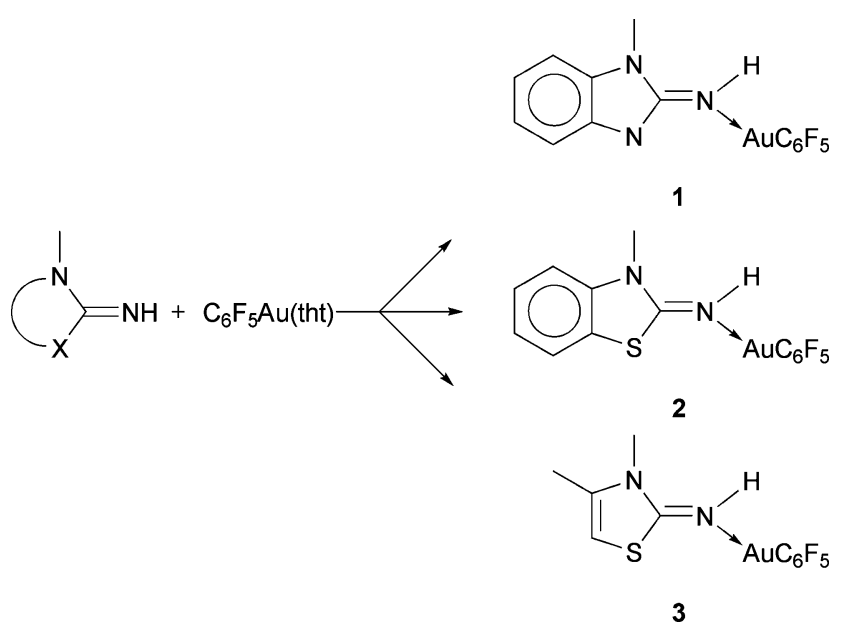

Scheme 2 Preparation of pfp gold(I) complexes of ligands I-III; X $=$ NMe or $\mathrm{S}$.

Compounds $\mathbf{1}$ and $\mathbf{2}$ are soluble in acetone, THF and DMSO while compound $\mathbf{3}$ is soluble in most organic solvents such as short chain alcohols, acetone, diethyl ether, THF, acetonitrile or dichloromethane. All of the complexes are insoluble in alkanes such as pentane and hexane. Gradual decomposition of compounds $\mathbf{1}$ and $\mathbf{2}$ was observed when stored under argon at $-22{ }^{\circ} \mathrm{C}$ 
for prolonged periods of time in both the solid state and solution. Compound 3, however, showed greater thermal stability and no decomposition was observed under the same conditions. Crystals suitable for X-ray structure determination were either obtained by vapour diffusion of pentane into a solution of the compound in THF (1 and $\mathbf{2}$ respectively) or by slow crystallisation from a concentrated acetone solution (3). All crystallisation mixtures were stored under argon at $-22{ }^{\circ} \mathrm{C}$.

\section{Phosphine gold(I) complexes}

Schmidbaur and co-workers ${ }^{12}$ have established that one equivalent of either $\left[\mathrm{Au}\left(\mathrm{PPh}_{3}\right)\left(\mathrm{SO}_{3} \mathrm{CF}_{3}\right)\right]$ or $\left[\mathrm{Au}\left(\mathrm{PPh}_{3}\right)\left(\mathrm{BF}_{4}\right)\right]$ reacts quantitatively with tetramethylguanidine or benzhydrylideneamine to form the corresponding monoaurated ylideneamine complex. Complexes 4-6 were prepared following a similar protocol by treating solutions of I, II or III with a suspension of (triphenylphosphine)gold(I) nitrate, $\left[\mathrm{Au}\left(\mathrm{NO}_{3}\right)\left(\mathrm{PPh}_{3}\right)\right]^{17}$ in diethyl ether at room temperature (Scheme 3). Since complexes 4-6 are insoluble in diethyl ether, free ligand traces could be removed from the crude product mixtures by washing with this solvent. Drying of the remaining solids in vacuo afforded the analytically pure products as colourless solids in high yield.

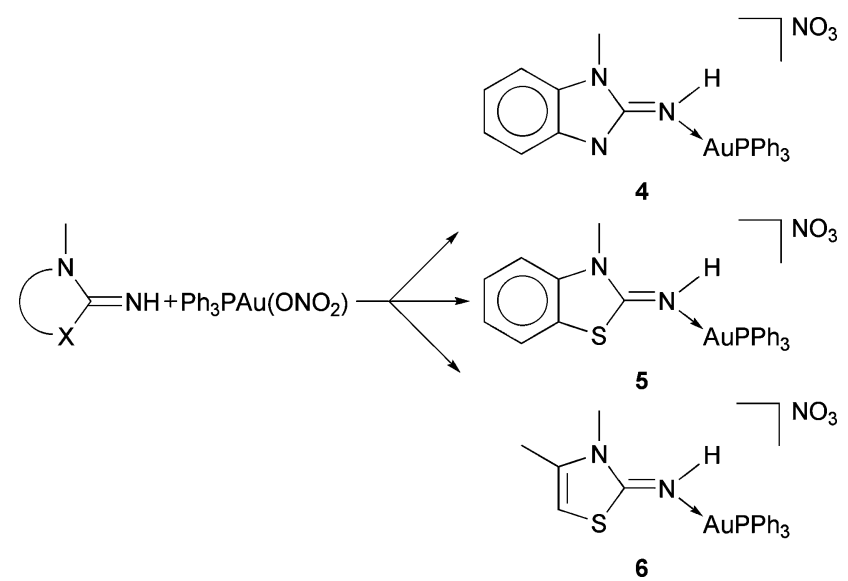

Scheme 3 Preparation of phosphine gold(I) complexes of ligands I-III; $\mathrm{X}=\mathrm{NMe}$ or $\mathrm{S}$.

The 'hard-soft' adducts 4-6 are neither air nor moisture sensitive. Moreover, these cationic complexes are soluble in more polar organic solvents such as short chain alcohols, acetone, dichloromethane, THF and DMSO. Their stability and good solubility makes them even more appealing candidates for biological screening, since the stability of such compounds in solution is a vital consideration for biological evaluation. All of the complexes are insoluble in water and alkanes such as hexane or pentane. Crystals suitable for X-ray crystal structure determinations were obtained by vapour diffusion of pentane into solutions of the compounds in acetone (4a) or dichloromethane (5) under argon at $-22{ }^{\circ} \mathrm{C}$.

\section{NHC gold(I) complexes}

Finally, the compound 1,3-di-tert-butylimidazol-2-ylidene-gold(I) nitrate, $\left[\mathrm{Au}\left(1,3-{ }^{\mathrm{t}} \mathrm{BuIm}-2\right.\right.$-ylidene $\left.)\left(\mathrm{NO}_{3}\right)\right]$, initially prepared by Baker and co-workers, ${ }^{18}$ was utilised in the high yield preparation of complex 7 - the first example of an ylideneamine gold(I) complex to also contain an NHC ligand (Scheme 4). Treatment of I with an equimolar amount of $\left[\mathrm{Au}\left(1,3-{ }^{\mathrm{t}} \mathrm{BuIm}-2\right.\right.$-ylidene $\left.)\left(\mathrm{NO}_{3}\right)\right]$ in THF at ambient temperature furnished 7.

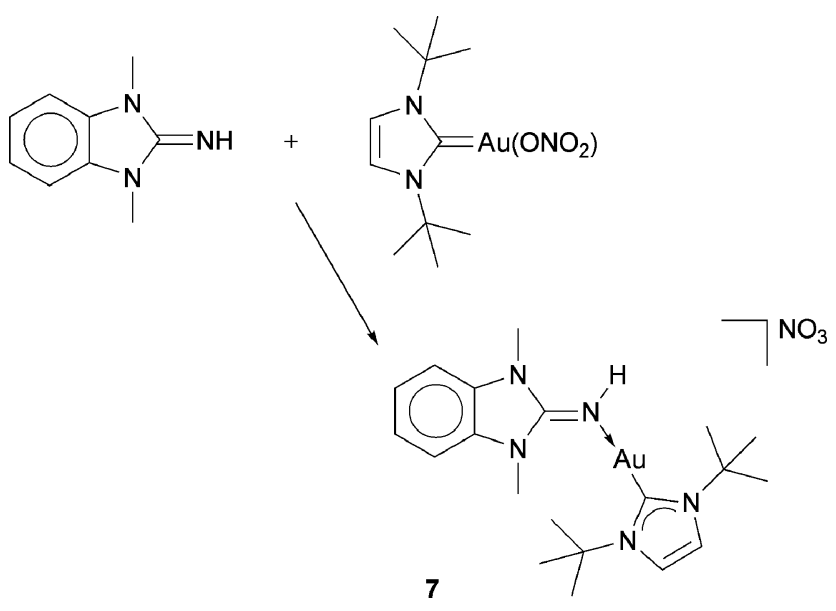

Scheme 4 Preparation of the NHC gold(I) complex of ligand $\mathbf{I}$.

Complex $\mathbf{7}$ is an off-white solid that is fairly air and moisture stable and soluble in organic solvents such as short chain alcohols, dichloromethane or DMSO but insoluble in water or alkanes. Crystals suitable for an X-ray structure determination were obtained under argon at $-22{ }^{\circ} \mathrm{C}$ by vapour diffusion of pentane into a solution of $\mathbf{7}$ in dichloromethane.

\section{Attempts at the deprotonation of ylideneamine complexes}

From close inspection of recorded ${ }^{1} \mathrm{H}$ NMR data (vide infra) it was evident that coordination of ligands I-III to a gold(I) centre has a significant effect on the electronic nature of the imine protons. This finding prompted deprotonation attempts on ylideneamine ligands following their coordination to a gold(I) centre. However, with complexes 4-6 as subjects, such attempts with KH proved unsuccessful and the bulk of all isolated materials consisted of the unmodified substrates (diagnostic NH resonances were still present in the ${ }^{1} \mathrm{H}$ NMR spectra). These findings were further confirmed by X-ray structure determination of crystalline materials isolated from all final product mixtures. Structure elucidation of colourless single crystals isolated after the deprotonation attempt on 4 by vapour diffusion of pentane into a solution of the product in $\mathrm{CH}_{2} \mathrm{Cl}_{2}$ at $-22{ }^{\circ} \mathrm{C}$ resulted in the structure $4 \mathbf{b}$. Also, in one of these trial experiments a variant of $\mathbf{6}$ that contains triflate as counterion, $\mathbf{6 b}$ (as colourless $\mathbf{6 b} \cdot \mathrm{CH}_{2} \mathrm{Cl}_{2}$ ), was crystallised by vapour diffusion of pentane into a solution of $\mathbf{6}$ in $\mathrm{CH}_{2} \mathrm{Cl}_{2}$ at $-22{ }^{\circ} \mathrm{C}$. Both these structures are discussed in the crystallographic section.

\section{Spectroscopic analysis}

\section{Nuclear magnetic resonance}

Most signals in the NMR $\left({ }^{1} \mathrm{H},{ }^{13} \mathrm{C},{ }^{31} \mathrm{P},{ }^{15} \mathrm{~N}\right)$ spectra of the new compounds appear slightly downfield to the chemical shifts of the corresponding starting materials. The NMe signals resonate at a characteristic $\delta 3.2-3.8$ in the ${ }^{1} \mathrm{H}$ NMR and $\delta 27-39$ in the ${ }^{13} \mathrm{C}$ NMR spectra. Although differences in concentration are 
known to influence the $\mathrm{NH}$ chemical shifts, it is notable that coordination to a gold(I) centre has a varied, but pronounced effect on the $\mathrm{NH}$ moiety of ligands I-III. In most cases $\mathrm{NH}$ resonances are shifted significantly downfield with respect to free ligand signals. This effect is most prominent for complex 1 and declines in the order $\mathbf{1}(\Delta \delta 4.27)>\mathbf{2}(\Delta \delta 2.77)>\mathbf{3}(\Delta \delta 1.45)$ in the first series of complexes and $5(\Delta \delta 4.20)>\mathbf{6}(\Delta \delta 2.87)$ in the second series of complexes, along with decreasing lone pair electron delocalization over the ligand system. In contrast, the NH resonances of complexes $\mathbf{4}$ and $\mathbf{7}$ experience a significant upfield shift ( $\Delta \delta 3.13$ and 1.98 respectively). Shielding of the NH proton in $\mathbf{4}$ and 7 by close association of the nitrate anion (even in solution), may represent a plausible explanation for this divergence. Additionally, a hydrogen bond between an oxygen atom of the anion and $\mathrm{NH}$ in the cation exists in the solid state ( NH ... O distance of $3.054 \AA$ in 4 and $2.956 \AA$ in 7). A similar situation was observed for the $\mathrm{NC}(\mathrm{H}) \mathrm{N}$ proton in $\left[\left\{\mu_{2}-\right.\right.$ $\left.\left.\mathrm{HCCCH}_{2} \mathrm{~N}=\mathrm{C}(\mathrm{H}) \mathrm{N}\left(\mathrm{CH}=\mathrm{CH}_{2}\right) \mathrm{CH}=\mathrm{CH}\right\} \mathrm{Co}_{2}(\mathrm{CO})_{6}\right]\left[\mathrm{B}\left(\mathrm{C}_{6} \mathrm{H}_{5}\right)\right]^{19}$ and ferrocenyl imidazolium salts. ${ }^{20}$

In the ${ }^{1} \mathrm{H}$ NMR spectra resonances of the phenyl protons of benzazole derived ligands clearly show the chemical inequivalence of the phenyl $\mathrm{CCH}$ and $\mathrm{CCHCH}$ protons upon changing from an $\mathrm{NMe}$ group (only two doublets of doublets detected) to an $\mathrm{S}$ atom (4 to 6 sets of signals observed). Interestingly, in the ${ }^{1} \mathrm{H}$ NMR spectra of compounds III, 3 and $\mathbf{6}$ the proton in the 5-position on the thiazole ring experiences an allylic ${ }^{4} J$ coupling of $\approx 1 \mathrm{~Hz}$ to the protons of the methyl substituent on the 4-position, resulting in a quartet or broad singlet at $\delta 5-6$ ( $\mathrm{CH}$ in 5-position) and a doublet at $\delta 2\left(\mathrm{NCH}_{3}\right)$.

In the ${ }^{13} \mathrm{C}$ NMR spectra very small to no changes are observed for $\mathrm{NCN}$ carbon shifts upon complexation in the benzimidazole compounds, whereas a significant downfield shift $(\Delta \delta$ 7.9-10.4) is observed in the thiazole based derivatives. In the case of the phenyl carbons of the benzazole ligands some carbons appear slightly downfield and others slightly upfield. This observation is not unusual as the total chemical shift $\sigma\left(\sigma=\sigma_{\mathrm{p}}+\sigma_{\mathrm{d}}\right)$ in the ${ }^{13} \mathrm{C}$ NMR reflects more than simply shielding and deshielding as in ${ }^{1} \mathrm{H}$ NMR. ${ }^{21}$ In the ${ }^{13} \mathrm{C}$ NMR spectra of $\mathbf{1 - 3}$, intricate $\mathrm{C}-$ $\mathrm{F}$ coupling patterns detected in the region $\delta 118-151$ verify the presence of a $\mathrm{Au}\left(\mathrm{C}_{6} \mathrm{~F}_{5}\right)$ unit. Similarly, in the spectra of 4-6, four additional sets of doublets are detected in the region $\delta$ 128-135 and correspond to the characteristic C-P coupling of the phenyl carbons of the $\left[\mathrm{Au}\left(\mathrm{PPh}_{3}\right)\right]^{+}$moiety. Of these, the doublet at $\delta$ 128.3-128.7 can be assigned to the C-P coupled ipso-carbon atom, whilst the doublet at $\delta 129.7$ is attributable to the C-P coupled meta-carbon atom. Resonances of the ortho- and para-carbon atoms are observed as doublets in the regions $\delta 134.4-134.5$ and $\delta$ 132.4-132.6, respectively. For the NHC complex 7, a significant downfield shift of $\Delta \delta 10.0$ is observed for the characteristic carbene carbon resonance relative to the signal for the same carbon in the precursor compound, $\left[\mathrm{Au}\left(1,3-{ }^{\mathrm{t}} \mathrm{BuIm}\right.\right.$-2-ylidene $\left.)\left(\mathrm{NO}_{3}\right)\right]{ }^{18}$

The ${ }^{15} \mathrm{~N}$ NMR spectrum of I exhibits a singlet at $\delta-278.0$ that corresponds to both endocyclic $\mathrm{N}$-atoms of the imidazole ring which are rendered magnetically and chemically equivalent by their environment. Despite the use of both indirect and direct methods, no resonance signal could be obtained for the exocyclic nitrogen atom. Coordination of $\mathbf{I}$ to a gold centre results in a slight downfield shift $(\Delta \delta 8.7)$ of the resonances of the endocyclic $\mathrm{N}$-atoms as is evident from the ${ }^{15} \mathrm{~N}$ NMR spectrum of
4. Unfortunately, all attempts to detect the metal-bonded nitrogen atom resonances in complex $\mathbf{4}$ failed.

In the ${ }^{31} \mathrm{P}$ NMR spectra of compounds 4-6, only one intense singlet at $\delta 32.0$ for $\mathbf{4}, \delta 27.7$ for $\mathbf{5}$ and $\delta 31.0$ for $\mathbf{6}$ is observed. These resonances all display an insignificant downfield shift relative to the precursor compound, $\left[\mathrm{Au}(\mathrm{NO})_{3}\left(\mathrm{PPh}_{3}\right)\right](\delta 28.9)$.

\section{Infrared spectroscopy}

Routine FT-IR data were collected for compounds I-III and 17 with all relevant absorption bands listed in the experimental section. However, an interesting observation made when the FTIR spectra of compounds 1-3 were compared to those of 4-7 deserves special mention. From this comparison it was evident that the coordination of ligands I-III to a neutral $\mathrm{Au}\left(\mathrm{C}_{6} \mathrm{~F}_{5}\right)$ moiety has a more pronounced effect on the $\mathrm{N}-\mathrm{H}$ stretching vibrations $(v(\mathrm{~N}-$ H) 3375-3399 $\mathrm{cm}^{-1}$ compared to $3249-3165 \mathrm{~cm}^{-1}$ for 4-7) than coordination to a positively charged $\left[\mathrm{Au}\left(\mathrm{PPh}_{3}\right)\right]^{+}$or $[\mathrm{Au}(\mathrm{NHC})]^{+}$ entity, although hydrogen bonding may also be reflected in the $\mathrm{N}-\mathrm{H}$ stretching vibrations.

\section{Mass spectrometry}

The FAB-MS spectra of compounds I and II display very little fragmentation owing to the mild nature of this ionization technique. The only diagnostic peaks present in the spectra of ligands I-III are those corresponding to the molecular ions and those resulting from the loss of a methyl group. A higher degree of fragmentation is evident in the EI-MS spectrum of III exhibiting an intense peak at $m / z$ 128. Even though no molecular ion peak is detected in the FAB-MS spectrum of $\mathbf{1}$, other diagnostic signals corresponding to the loss of a $\mathrm{CH}_{3}$ group $(\mathrm{m} / z$ 511), and further loss of $\mathrm{Au}\left(\mathrm{C}_{6} \mathrm{~F}_{5}\right)(\mathrm{m} / z$ 147) are present. A molecular ion peak was detected in the spectrum of 2 , while $m / z$ values that correspond to their cations are present for 4-6. In these spectra, signals attributable to the homoleptic rearrangement product $\left[\mathrm{Au}\left(\mathrm{PPh}_{3}\right)_{2}\right]^{+}$are also present at $m / z$ 720. Although FAB-MS analysis was executed for $\mathbf{3}$, this technique, despite the soft nature thereof, proved unsuccessful for this complex and the acquired spectra failed to deliver any diagnostic peaks.

\section{Crystallography}

The crystal and molecular structures of compounds I, III, IV $\dagger$ and 1-7 (4a $\dagger$ ) were determined by single crystal X-ray diffraction and are now, to the best of our knowledge, reported for the first time (Fig. 1-10). In addition, compounds 1-7 represent the first reported examples of gold complexes to contain 2-ylideneaminefunctionalised heterocycles as ligands. In view of the fact that very few crystal structures of ylideneamine-functionalised heterocyclic ligands have been reported in the literature, a discussion of the free ligand structures is included here to serve as a point of reference and to place the characterization of this class of compounds on a firm footing.

Where more than one unique molecule is present in the asymmetric unit (structures III, IV and 1) no significant differences in bond lengths and angles of the distinct molecules were observed. Seven of the compounds crystallised with included solvent molecules $\left(\mathbf{I} \cdot 3 \mathrm{H}_{2} \mathrm{O}\right.$, IV $\cdot \mathrm{CH}_{2} \mathrm{Cl}_{2}, \mathbf{2} \cdot \mathrm{THF}, \mathbf{3} \cdot \mathrm{Me}_{2} \mathrm{CO}, \mathbf{4 a} \cdot 2 \mathrm{Me}_{2} \mathrm{CO} \dagger$, 6b. $0.33 \mathrm{H}_{2} \mathrm{O}$ and $7 \cdot 0.5 \mathrm{CH}_{2} \mathrm{Cl}_{2}$ ). The very extended network of 


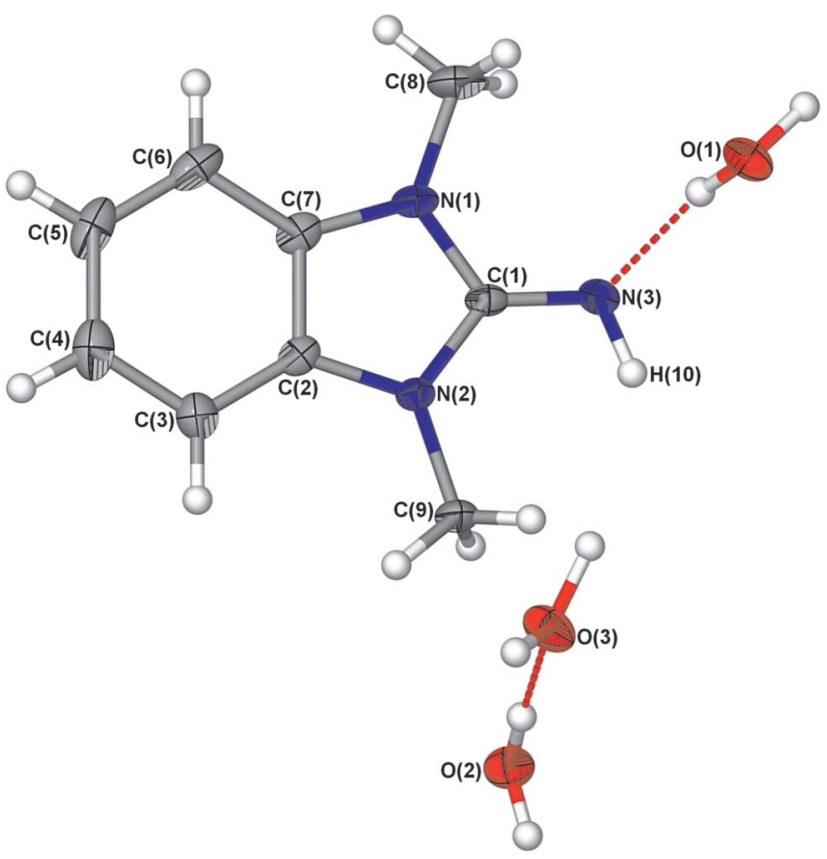

Fig. 1 Molecular structure of $\mathbf{I} \cdot 3 \mathrm{H}_{2} \mathrm{O}$ (thermal ellipsoids drawn at $50 \%$ probability level). Selected bond lengths $(\AA)$ and angles $\left({ }^{\circ}\right)$ : $\mathrm{N}(3)-\mathrm{C}(1)$ 1.295(3), $\mathrm{N}(1)-\mathrm{C}(1)$ 1.375(3), $\mathrm{N}(2)-\mathrm{C}(1)$ 1.374(2), $\mathrm{N}(1)-\mathrm{C}(8)$ 1.451(3), $\mathrm{N}(2)-\mathrm{C}(9)$ 1.451(3), H(10)-N(3)-C(1) 111(2), N(3)-C(1)-N(1) 123.5(2), $\mathrm{N}(3)-\mathrm{C}(1)-\mathrm{N}(2) 130.2(2), \mathrm{N}(1)-\mathrm{C}(1)-\mathrm{N}(2)$ 106.3(2).
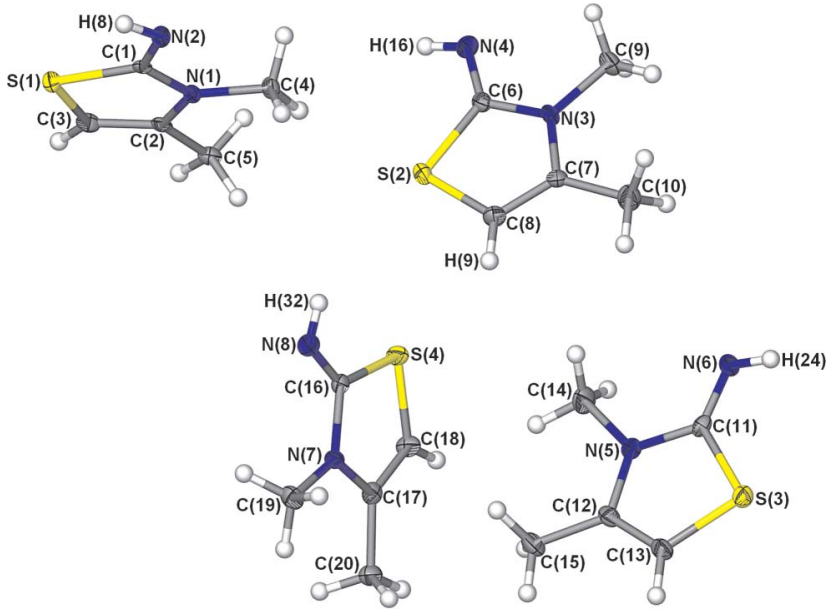

Fig. 2 Molecular structure of III showing the numbering scheme of the four unique molecules in the asymmetric unit (thermal ellipsoids drawn at $50 \%$ probability level). Selected bond lengths $(\AA)$ and angles $\left({ }^{\circ}\right)$ for only one of the molecules: $\mathrm{N}(2)-\mathrm{C}(1) 1.280(3), \mathrm{N}(1)-\mathrm{C}(1)$ 1.372(4), $\mathrm{S}(1)-\mathrm{C}(1)$ 1.781(3), N(1)-C(4) 1.455(3), H(8)-N(2)-C(1) 110(2), N(2)-C(1)-N(1) 123.5(3), N(2)-C(1)-S(1) 128.5(2), N(1)-C(1)-S(1) 108.0(2).

hydrogen bonding in I, forming layers consisting of cyclic water hexamers, is noteworthy. Devoid of any disorder as a result of solvent inclusion, the crystal structure refinement of $\mathbf{4 b}$ is of superior quality than that of $\mathbf{4 a}$ (solvate with acetone $\dagger$ ), thus the more reliable bond lengths and angles obtained for $\mathbf{4 b}$ are used in comparisons in the discussion.

The bi-coordinated gold complexes are all linear or approaching linearity with $\mathrm{L}^{1}-\mathrm{Au}-\mathrm{L}^{2}$ angles varying from $174.8(1)^{\circ}$ in 7 to $178.8(2)^{\circ}$ in 3 . Furthermore, the molecular structures of the

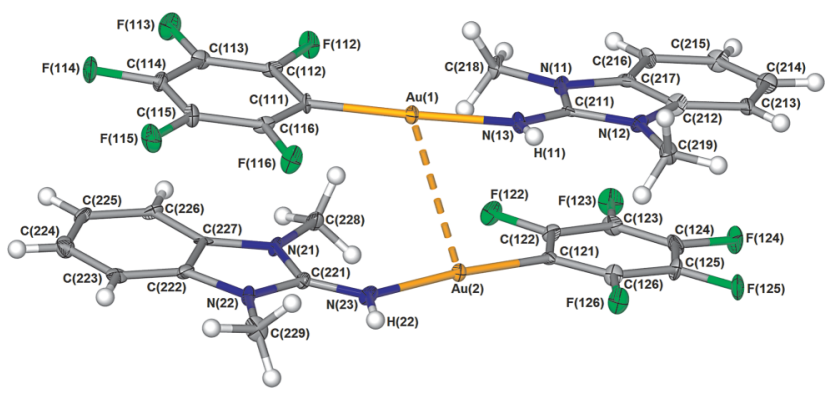

Fig. 3 Molecular structure of $\mathbf{1}$ showing two unique molecules present in the asymmetric unit, connected via a weak aurophilic interaction (thermal ellipsoids drawn at $50 \%$ probability level). Selected bond lengths $(\AA)$ and angles $\left({ }^{\circ}\right): \mathrm{Au}(1) \cdots \mathrm{Au}(2)$ 3.5824(6), $\mathrm{Au}(1)-\mathrm{C}(111)$ 2.009(7), $\mathrm{Au}(1)-\mathrm{N}(13)$ 2.041(5), N(13)-C(211) 1.305(8), N(11)-C(211) 1.373(8), N(12)-C(211) 1.374(8), N(11)-C(218) 1.466(8), N(12)-C(219) 1.456(8), N(13)-Au(1)-C(111) 176.4 (2), N(13)-Au(1)-Au(2) 73.4(2), $\mathrm{C}(111)-\mathrm{Au}(1)-\mathrm{Au}(2) \quad 109.9(2), \quad \mathrm{C}(211)-\mathrm{N}(13)-\mathrm{Au}(1) \quad 133.5(5), \quad \mathrm{N}(11)-$ $\mathrm{C}(211)-\mathrm{N}(13)$ 126.4(6), N(12)-C(211)-N(13) 126.5(6), N(11)-C(211)$\mathrm{N}(12)$ 107.3(6).

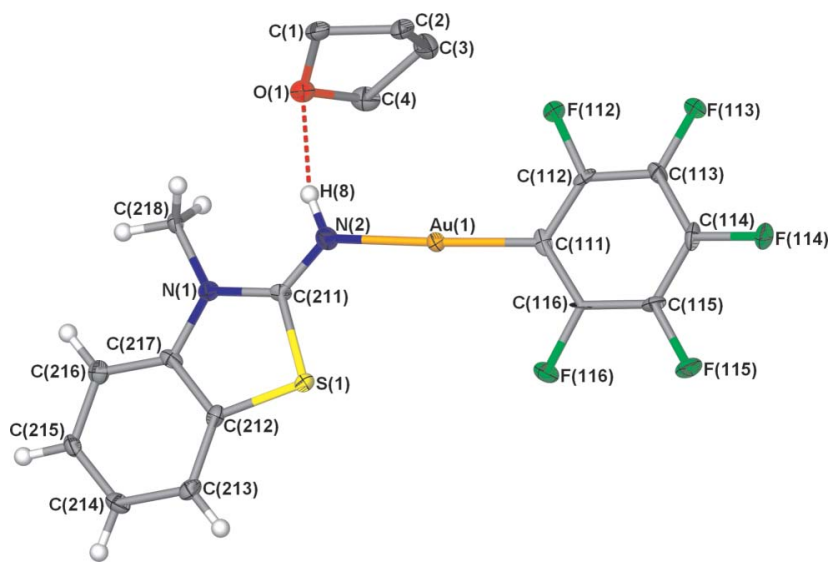

Fig. 4 Molecular structure of 2.THF showing the numbering scheme (thermal ellipsoids drawn at $50 \%$ probability level). THF hydrogen atoms are omitted for clarity. Selected bond lengths $(\AA)$ and angles $\left({ }^{\circ}\right): \mathrm{Au}(1)-\mathrm{C}(111)$ 2.009(5), $\mathrm{Au}(1)-\mathrm{N}(2)$ 2.037(5), $\mathrm{N}(2)-\mathrm{C}(211) \quad 1.294(7), \quad \mathrm{N}(1)-\mathrm{C}(211) \quad 1.359(7), \quad \mathrm{S}(1)-\mathrm{C}(211) \quad 1.763(5)$, $\mathrm{N}(1)-\mathrm{C}(218)$ 1.425(7), N(2)-Au(1)-C(111) 177.3(2), C(211)-N(2)-Au(1) 127.0(4), $\quad \mathrm{N}(1)-\mathrm{C}(211)-\mathrm{N}(2) \quad 126.6(5), \quad \mathrm{S}(1)-\mathrm{C}(211)-\mathrm{N}(2) \quad 122.3(4)$, $\mathrm{N}(1)-\mathrm{C}(211)-\mathrm{S}(1)$ 111.1(4).

compounds consist of either a $\mathrm{Au}\left(\mathrm{C}_{6} \mathrm{~F}_{5}\right)$ fragment (in 1-3), a $\left[\mathrm{Au}\left(\mathrm{PPh}_{3}\right)\right]^{+}$unit (in 4-6b) or a $[\mathrm{Au}(\mathrm{NHC})]^{+}$unit (in 7) coordinated to the imine nitrogen of the neutral ligand. This then affords neutral (1-3) or charged complexes neutralised by nitrate $(\mathbf{4}, \mathbf{5}$ and 7) or triflate (6b) anions hydrogen bonded to the imine proton. The two ring systems present in $\mathbf{1}$ and $\mathbf{3}$ approach co-planarity with interplanar angles of $6.9^{\circ}, 7.4^{\circ}$ and $9.4^{\circ}$, whilst being almost perfectly aligned in $2\left(1.6^{\circ}\right)$. Conversely, the ring systems in 7 take on an approximate perpendicular disposition $\left(74.7^{\circ}\right)$ in order to minimise steric interactions between the ligands.

Although a comparison of the solid state FT-IR spectroscopic data of compounds 1 and $\mathbf{4}$ suggests that coordination of ligand I to a $\mathrm{Au}\left(\mathrm{C}_{6} \mathrm{~F}_{5}\right)$ unit has a more pronounced effect on the stretching vibrations of the $\mathrm{N}-\mathrm{H}$ moiety than coordination to a $\left[\mathrm{Au}\left(\mathrm{PPh}_{3}\right)\right]^{+}$unit, no appreciable difference between the $\mathrm{C}=\mathrm{N}$ bond lengths in $\mathbf{1}$ and $\mathbf{4}$ is observed. However, as we have warned 


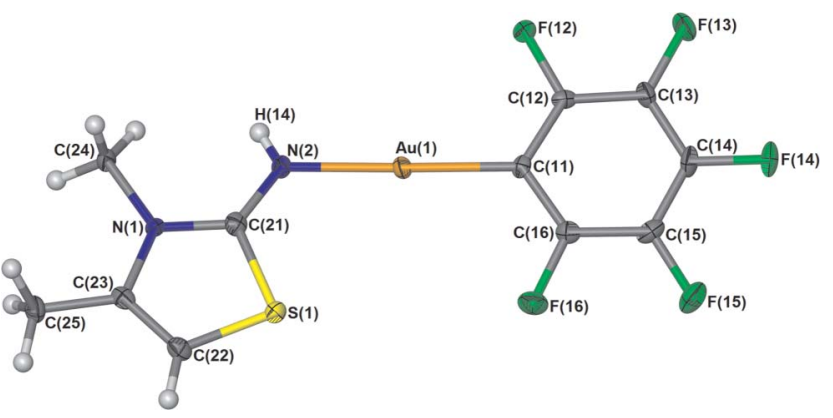

Fig. 5 Molecular structure of $\mathbf{3} \cdot \mathrm{Me}_{2} \mathrm{CO}$ showing the numbering scheme (thermal ellipsoids drawn at $50 \%$ probability level). Solvent molecules are not shown. Selected bond lengths $(\AA)$ and angles $\left({ }^{\circ}\right)$ : $\mathrm{Au}(1)-\mathrm{C}(11)$ 2.002(5), $\mathrm{Au}(1)-\mathrm{N}(2)$ 2.031(4), N(2)-C(21) 1.292 (6), N(1)-C(21) 1.359(6), $\mathrm{S}(1)-\mathrm{C}(21)$ 1.748(5), N(1)-C(24) 1.466(6), N(2)-Au(1)-C(11) 178.8(2), $\mathrm{C}(21)-\mathrm{N}(2)-\mathrm{Au}(1)$ 125.3(3), N(1)-C(21)-N(2) 128.2(5), $\mathrm{S}(1)-\mathrm{C}(21)-\mathrm{N}(2)$ 121.8(4), N(1)-C(21)-S(1) 109.9(4).

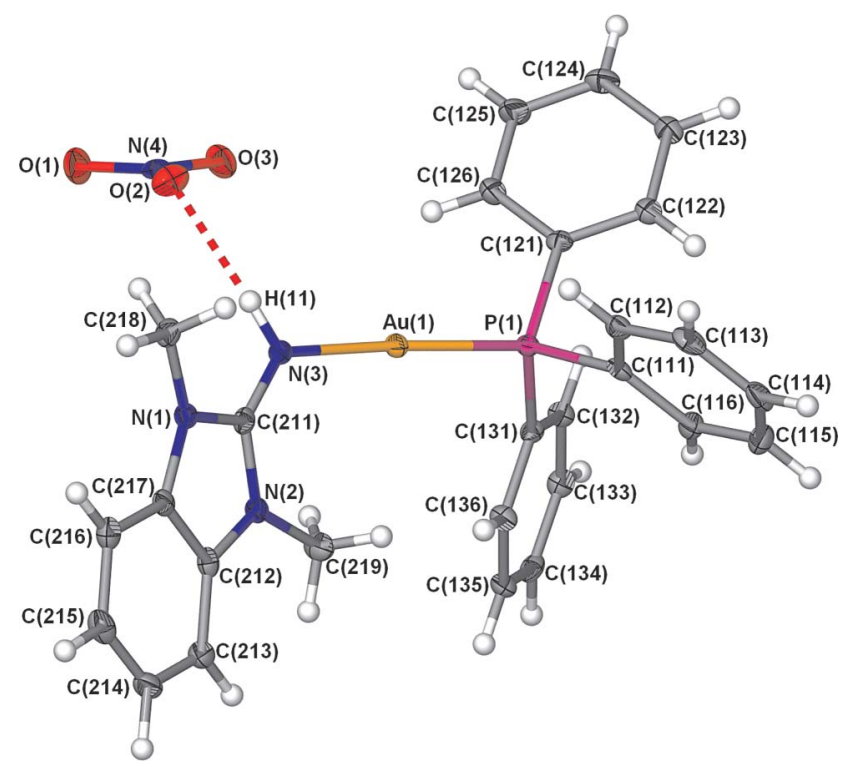

Fig. 6 Molecular structure of $\mathbf{4 b}$ showing the numbering scheme (thermal ellipsoids drawn at $50 \%$ probability level). Selected bond lengths $(\AA)$ and angles $\left(^{\circ}\right)$ : $\mathrm{Au}(1)-\mathrm{P}(1)$ 2.231(1), $\mathrm{Au}(1)-\mathrm{N}(3)$ 2.040(3), $\mathrm{N}(3)-\mathrm{C}(211) \quad 1.309(4), \quad \mathrm{N}(1)-\mathrm{C}(211)$ 1.373(5), $\mathrm{N}(2)-\mathrm{C}(211)$ 1.392(4), N(1)-C(218) 1.458(4), N(2)-C(219) 1.460(4), N(3)-Au(1)-P(1) 175.60(8), $\quad \mathrm{C}(211)-\mathrm{N}(3)-\mathrm{Au}(1) \quad 129.7(3), \quad \mathrm{N}(1)-\mathrm{C}(211)-\mathrm{N}(3) \quad 125.8(3)$, $\mathrm{N}(2)-\mathrm{C}(211)-\mathrm{N}(3)$ 126.7(3), N(1)-C(211)-N(2) 107.5(3).

before, correlation of such connectivity data with other analytical results should be interpreted with the utmost caution. ${ }^{22}$

Bond lengths and angles in the imine ligand are not significantly changed by gold(I) coordination and are comparable to those in 1,3-dimethyl-1,3-dihydro-imidazol-2-ylidineamine ${ }^{13}$ and standard values for such bonds. ${ }^{23}$ Contrary to ${ }^{15} \mathrm{~N}$ NMR observations in solution, $\mathrm{C}=\mathrm{N}$ and $\mathrm{C}-\mathrm{N}$ bond lengths differ significantly and do not testify to any substantial electron delocalisation over these bonds in the solid state. The ylideneamine ligands are all essentially planar with only the methyl hydrogens protruding from the plane. From a comparison of the bond lengths and angles it is evident that variations amongst alike bonds are small.

Nevertheless, a few observations are in order. The $\mathrm{Au}-\mathrm{P}$ bond lengths $(\mathbf{4 b}, \mathbf{5}, \mathbf{6 b})$ are similar to those reported

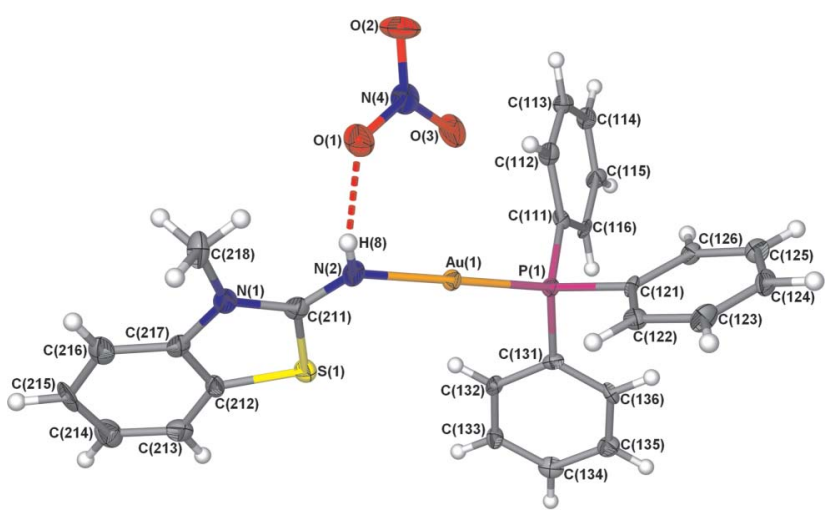

Fig. 7 Molecular structure of $\mathbf{5}$ showing the numbering scheme (thermal ellipsoids drawn at $50 \%$ probability level). Selected bond lengths $(\AA)$ and angles $\left({ }^{\circ}\right)$ : $\quad \mathrm{Au}(1)-\mathrm{P}(1)$ 2.2245(18), $\mathrm{Au}(1)-\mathrm{N}(2)$ 2.028(6), $\mathrm{N}(2)-\mathrm{C}(211) \quad 1.289(9), \quad \mathrm{N}(1)-\mathrm{C}(211) \quad 1.359(9), \quad \mathrm{S}(1)-\mathrm{C}(211)$ 1.770(8), N(1)-C(218) 1.421(9), S(1)-C(212) 1.755(7), N(2)-Au(1)-P(1) 178.43(18), $\mathrm{C}(211)-\mathrm{N}(2)-\mathrm{Au}(1)$ 127.3(5), N(2)-C(211)-S(1) 120.0(6), $\mathrm{N}(1)-\mathrm{C}(211)-\mathrm{N}(2) 128.6(7), \mathrm{N}(1)-\mathrm{C}(211)-\mathrm{S}(1) 111.5(5)$.

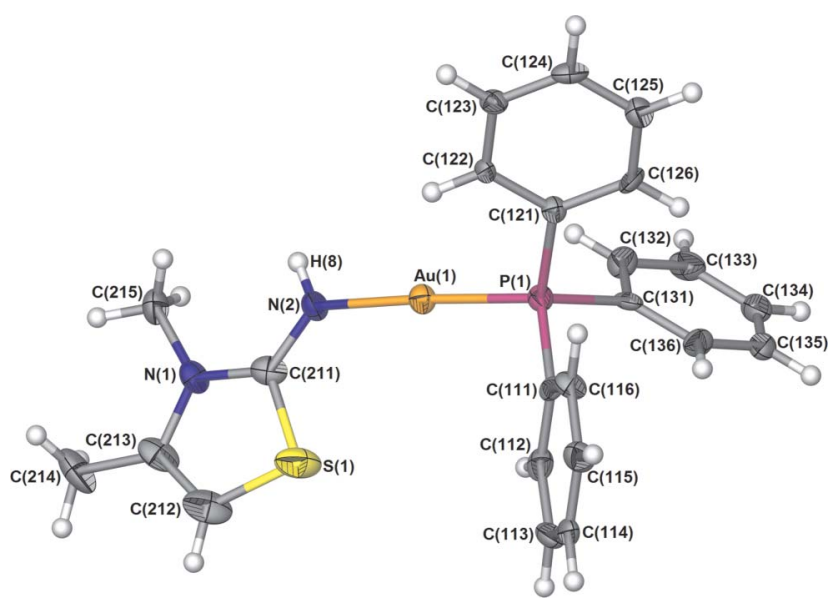

Fig. 8 Molecular structure of $\mathbf{6 b} \cdot 0.33 \mathrm{H}_{2} \mathrm{O}$ showing the numbering scheme (thermal ellipsoids drawn at $50 \%$ probability level). The solvent molecule as well as the disordered counterion is omitted for clarity. Selected bond lengths $(\AA)$ and angles $\left({ }^{\circ}\right)$ : $\mathrm{Au}(1)-\mathrm{P}(1) 2.229(1), \mathrm{Au}(1)-\mathrm{N}(2)$ 2.036(4), $\mathrm{N}(2)-\mathrm{C}(211)$ 1.294(7), $\mathrm{N}(1)-\mathrm{C}(211)$ 1.353(7), $\mathrm{S}(1)-\mathrm{C}(211)$ 1.732(6), N(1)-C(215) 1.454(7), S(1)-C(212) 1.732(6), N(2)-Au(1)-P(1) 177.2(1), $\quad \mathrm{C}(211)-\mathrm{N}(2)-\mathrm{Au}(1) \quad 124.2(4), \quad \mathrm{N}(2)-\mathrm{C}(211)-\mathrm{S}(1) \quad 122.9(4)$, $\mathrm{N}(1)-\mathrm{C}(211)-\mathrm{N}(2)$ 127.0(5), N(1)-C(211)-S(1) 110.1(4).

for $\left[\mathrm{Au}\left\{\mathrm{NH}=\mathrm{C}\left(\mathrm{NMe}_{2}\right)_{2}\left(\mathrm{PPh}_{3}\right)\right\}\right]\left[\mathrm{CF}_{3} \mathrm{SO}_{3}\right]$ and $\left[\mathrm{Au}\left(\mathrm{NH}=\mathrm{CPh}_{2}\right)\right.$ $\left.\left(\mathrm{PPh}_{3}\right)\right]\left[\mathrm{BF}_{4}\right]\left(2.229(2) \AA\right.$ and 2.234(2) $\AA$, respectively). ${ }^{12}$ Furthermore, the $\mathrm{Au}-\mathrm{P}$ (in $\mathbf{4 b}, \mathbf{5}, \mathbf{6 b}$ ) and $\mathrm{Au}-\mathrm{C}$ (carbene) (in 7) separations are significantly larger than in the corresponding starting gold compounds. This can be ascribed to the larger trans influence of the ylideneamine ligand (much larger for trans $\mathrm{Au}-\mathrm{P}$ than trans $\mathrm{Au}-\mathrm{C}($ carbene $)$ ) compared to that of the nitrate ligand (2.208(3) $\AA^{24}$ and 1.973(4) $\left.\AA^{17}\right)$. Thirdly, the $\mathrm{Au}-\mathrm{N}$ bond in the ylideneamine seems to be relatively insensitive to changes in the ligand itself or to influences by ligands positioned trans thereto. Values vary between 2.03(4) $\AA$ (in 3, 5, and 7) and $2.04 \AA$ (in 1). These distances are comparable to that reported for $\left[\mathrm{Au}\left(\mathrm{C}_{6} \mathrm{~F}_{5}\right)\left\{\mathrm{N}(\mathrm{H})=\mathrm{CPh}_{2}\right\}\right](2.044(8) \AA),{ }^{25}$ as well as for other examples wherein the gold(I) centre is coordinated to an endocyclic $\mathrm{N}$-atom. ${ }^{16,26}$ Similar $\mathrm{Au}-\mathrm{N}$ separations have also been reported 


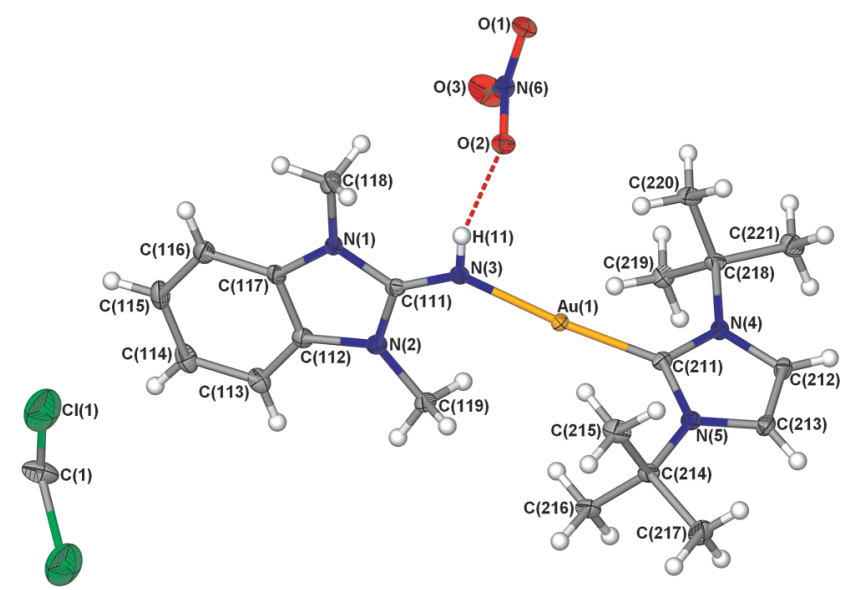

Fig. 9 Molecular structure of $7 \cdot 0.5 \mathrm{CH}_{2} \mathrm{Cl}_{2}$ showing the numbering scheme (thermal ellipsoids drawn at $50 \%$ probability level). Selected bond lengths $(\AA)$ and angles $\left({ }^{\circ}\right)$ : $\mathrm{Au}(1)-\mathrm{C}(211)$ 1.993(4), $\mathrm{Au}(1)-\mathrm{N}(3) \quad 2.028(3), \quad \mathrm{N}(3)-\mathrm{C}(111) \quad 1.299(5), \quad \mathrm{N}(1)-\mathrm{C}(111)$ 1.373(5), $\mathrm{N}(2)-\mathrm{C}(111) \quad 1.378(5), \quad \mathrm{N}(4)-\mathrm{C}(211) \quad 1.363(5), \mathrm{N}(5)-\mathrm{C}(211) \quad 1.364(5)$, $\mathrm{N}(1)-\mathrm{C}(118) \quad 1.458(5), \quad \mathrm{N}(2)-\mathrm{C}(119) \quad 1.452(5), \quad \mathrm{N}(4)-\mathrm{C}(218) \quad 1.508(5)$, $\mathrm{N}(5)-\mathrm{C}(214)$ 1.503(5), N(3)- $\mathrm{Au}(1)-\mathrm{C}(211)$ 174.8(1), C(111)-N(3)-Au(1) 134.5(3), $\quad \mathrm{N}(1)-\mathrm{C}(111)-\mathrm{N}(3) \quad 126.0(4), \quad \mathrm{N}(2)-\mathrm{C}(111)-\mathrm{N}(3) \quad 127.0(3)$, $\mathrm{N}(1)-\mathrm{C}(111)-\mathrm{N}(2)$ 107.0(3), N(4)-C(211)-Au(1) 126.3(3), N(5)-C(211)$\mathrm{Au}(1)$ 128.1(3), N(4)-C(211)-N(5) 105.5(3).

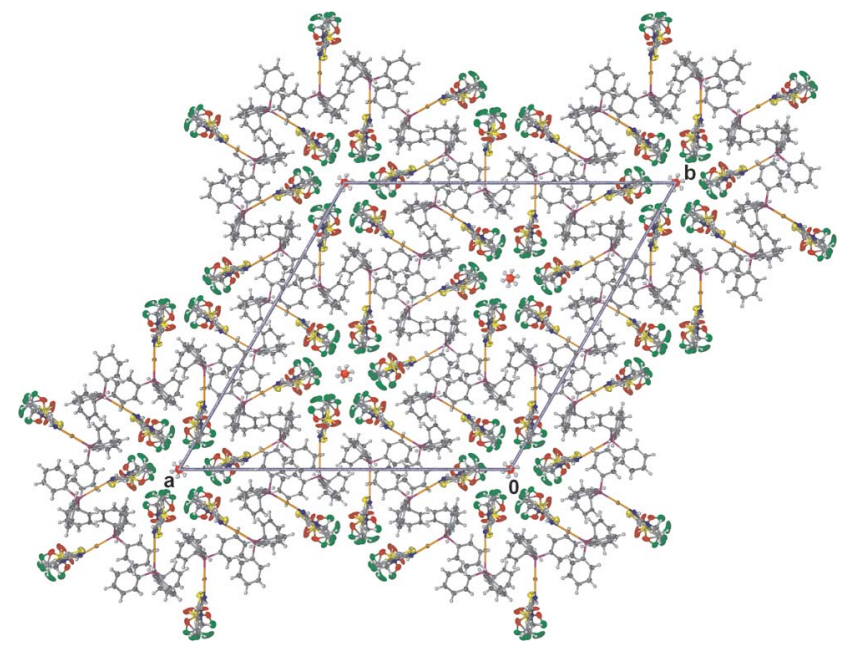

Fig. 10 Flower-like appearance of the solid state packing of $\mathbf{6 b}$ viewed along the $c$-axis.

for the $\left[\mathrm{Au}(\right.$ imine $\left.)\left(\mathrm{PPh}_{3}\right)\right]$ complexes $\left[\mathrm{Au}\left(\mathrm{NH}=\mathrm{CPh}_{2}\right)\left(\mathrm{PPh}_{3}\right)\right]\left[\mathrm{BF}_{4}\right]$ and $\left[\mathrm{Au}\left\{\mathrm{NH}=\mathrm{C}\left(\mathrm{NMe}_{2}\right)_{2}\right\}\left(\mathrm{PPh}_{3}\right)\right]\left[\mathrm{CF}_{3} \mathrm{SO}_{3}\right] \quad(2.036(7) \AA$ and $2.044(9) \AA$, respectively) ${ }^{12}$ and also for the [Au(imine)(NHC)] complex $\left[\mathrm{Au}_{2}\left(\mathrm{CH}_{3} \mathrm{im}\left(\mathrm{CH}_{2} \text { py) }\right)_{2}\right]\left(\mathrm{BF}_{4}\right)_{2}(2.087(8)){ }^{27}\right.$ Finally, the $\mathrm{Au}-\mathrm{C}$ bond distances are very similar in the reactant $\left[\mathrm{Au}\left(\mathrm{C}_{6} \mathrm{~F}_{5}\right)(\mathrm{tht})\right],{ }^{15}$ product $\left[\mathrm{Au}\left(\mathrm{C}_{6} \mathrm{~F}_{5}\right)\right.$ (ylideneamine) $]$ (1-3) or literature example, $\left.\left[\mathrm{Au}\left(\mathrm{C}_{6} \mathrm{~F}_{5}\right)\left(\mathrm{NH}=\mathrm{CH}_{2}\right)\right]\right]^{25,28}$ suggesting that a rather similar electronic influence is exercised by these particular $\mathrm{S}$ - and $\mathrm{N}$-donor ligands.

Hydrogen bonding involving the imine nitrogen and either included solvent molecules (in I, $\mathbf{2}$ and $\mathbf{3}$ ) or the anions (in $\mathbf{4}$ 7), together with $\pi-\pi$ stacking interactions (in I, IV, 1-3, 4a and 7) govern solid state packing. With the exception of $\mathbf{1}$, no aurophilic interactions were observed in the solid state packing of the remaining complexes. These interactions between neighbouring molecules are most likely prohibited by the steric demands of included solvent molecules as well as a strong preference for the formation of hydrogen bonds. This favouring of hydrogen bonding over aurophilic associations may well be an enthalpy effect. Although the energy of an aurophilic interaction (29$33 \mathrm{~kJ} \mathrm{~mol}^{-1}$ ) has been estimated by NMR experiments to be of the same order of magnitude as a typical hydrogen bond (20$\left.30 \mathrm{~kJ} \mathrm{~mol}^{-1}\right),{ }^{29}$ the hydrogen bond per molecule ratio in the crystal lattices is $2: 2$ or more whereas the aurophilic bond per molecule ratio would be $1: 2$. The formation of twice as many hydrogen bonds therefore results in a much greater energy gain compared to association via aurophilic bonds. This observation is in agreement with a report by Laguna and co-workers, ${ }^{25}$ who have concluded that hydrogen-bonding may compete with aurophilic interactions.

In the solid state packing of compound $\mathbf{6} \mathbf{b}$, which crystallises in a high symmetry trigonal system, the molecules are assembled in groups of six stabilised by a relatively strong hydrogen bond involving the imine hydrogen atoms and oxygen atoms of the triflate counter anion ( $\mathrm{N}-\mathrm{H} \cdots \mathrm{O}, 2.06-2.11 \AA)$. This arrangement, when viewed along the $c$-axis, bestows a beautiful flower-like appearance upon the crystal lattice (Fig. 10). The core of the flower motif consists of six triflate counterions arranged about a central water molecule whilst the 'petals' comprise six cationic complexes of $\mathbf{6} \mathbf{b}$, connected to the inner part via hydrogen bonding. It is possible that loss of the originally included solvent molecules followed by water absorption, to fill the resulting voids, may account for the presence of water in the crystal lattice. This process may also have caused the observed disorder in the triflate ion, as one of the disordered anions interacts weakly with a water molecule via an $\mathrm{O}-\mathrm{H} \cdots \mathrm{F}$ interaction.

\section{Cytotoxicity studies}

\section{Anticancer activity}

The in vitro cytotoxicity of compounds 4-7, at varying concentrations in DMSO, was determined using cervical carcinoma cells (HeLa; ATCC CCL-2) as the target cell line. Identical assays were also performed on ligands I-III, serving as control experiments to ensure that any growth inhibition observed is indeed the result of auration and not only due to an inherent activity of the free ligands. Drug-free solvent controls were included. Also reported are the $\mathrm{IC}_{50}$ data determined under the same conditions for cisplatin, a well-established anticancer drug frequently used as a standard in drug performance comparisons. To evaluate whether any cytotoxicity observed against HeLa cells may not be tumour specific, additional dose-response assays were performed to derive $\mathrm{IC}_{50}$ values against resting and phytohaemagglutinin(PHA)-stimulated human lymphocytes.

The results obtained for these preliminary studies are summarised in Table 1. None of the tested compounds showed extensive cytotoxic potential, with the free ligands I, II and III resulting in the least growth inhibition, having $\mathrm{IC}_{50}$ values greater that $30 \mu \mathrm{M}$. The lack of cytotoxicity observed for these compounds could also reflect a low degree of cellular uptake which is determined by their hydrophilicity. Although all of complexes $\mathbf{4}$, 5, 6 and 7 induced a significant increase in growth inhibition with 
Table 1 Cytotoxicity studies against cervical carcinoma cells (HeLa; ATCC CCL-2)

\begin{tabular}{|c|c|c|c|c|}
\hline Compound & $\mathrm{HeLa} \mathrm{IC}_{50}{ }^{a}(\mu \mathrm{M})$ & $\begin{array}{l}\text { Lymphocyte } \\
\text { resting }(\mu \mathrm{M})\end{array}$ & $\begin{array}{l}\text { Lymphocyte } \\
\text { stimulation } \\
(\mu \mathrm{M})\end{array}$ & $\begin{array}{l}\text { Tumor } \\
\text { specificity }\end{array}$ \\
\hline I & $>50$ & $b$ & $b$ & $b$ \\
\hline II & $32.2 \pm 3.0$ & $b$ & $b$ & $b$ \\
\hline III & $>50$ & $b$ & $b$ & $b$ \\
\hline 4 & $10.2 \pm 0.4$ & $6.4 \pm 1.3$ & $3.4 \pm 2.0$ & 0.5 \\
\hline 5 & $27.3 \pm 4.0$ & $3.6 \pm 0.3$ & $4.0 \pm 0.3$ & 0.08 \\
\hline 6 & $9.1 \pm 0.3$ & $6.1 \pm 1.2$ & $4.3 \pm 0.7$ & 0.6 \\
\hline 7 & $19.2 \pm 0.3$ & $6.5 \pm 0.2$ & $6.8 \pm 1.0$ & 0.3 \\
\hline cisplatin & 0.6 & $30.4 \pm 6.7$ & $2.2 \pm 0.3$ & - \\
\hline
\end{tabular}

${ }^{a} \mathrm{IC}_{50}$ values refer to the minimum concentration required to effect growth inhibition in $50 \%$ of the cells. ${ }^{b}$ Not performed.

Table 2 Parasite-inhibitory and haemolytic properties

\begin{tabular}{lll}
\hline Compound & $\mathrm{IC}_{50}{ }^{a}\left(\mu \mathrm{g} \mathrm{ml}^{-1}\right)$ & $50 \%$ hemolysis $\left(\mu \mathrm{g} \mathrm{ml}^{-1}\right)$ \\
\hline $\mathbf{I}$ & $40.9 \pm 1.0$ & No haemolysis \\
II & $7.2 \pm 1.5$ & No haemolysis \\
III & $>100$ & No haemolysis \\
$\mathbf{4}$ & $5.8 \pm 1.1$ & 50 \\
$\mathbf{5}$ & $5.2 \pm 1.3$ & $25-50$ \\
$\mathbf{6}$ & $4.4 \pm 1.1$ & $25-50$ \\
$\mathbf{7}$ & $5.1 \pm 1.1$ & $50-100$ \\
chloroquine & $0.0091 \pm 0.00086$ & No haemolysis
\end{tabular}

${ }^{a} \mathrm{IC}_{50}$ values refer to the compound concentration required to effect a $50 \%$ growth inhibition of the cells.

respect to the free ligands, the measured $\mathrm{IC}_{50}$ values were still not comparable to that of cisplatin.

However, it can safely be concluded that coordination to a $\left[\mathrm{Au}\left(\mathrm{PPh}_{3}\right)\right]^{+}$moiety has the greatest effect on ligand $\mathbf{I}$ with the $\mathrm{IC}_{50}$ value changing from greater than $50 \mu \mathrm{M}$ to 10.17 $\mu \mathrm{M}$. Furthermore, gold(I) coordination of ligand II to afford complex $\mathbf{5}$ does not bring about any large changes in the cytotoxic potency; the tumour specificity, however, decreases drastically. Although complex 6 displays the greatest growth inhibition as well as tumour specificity, the measured lymphocyte resting and stimulation values are of intermediate nature in the series. From a comparison of the effects of complexes $\mathbf{4}$ and 7, it is evident that the triphenylphosphine ancillary ligand imparts greater cytotoxicity and tumour specificity on the complex than its NHC counterpart.

\section{Antimalarial activity}

Preliminary in vitro antimalarial activity studies were carried out by performing dose-response assays against the 3D7 strain of Plasmodium falciparum. The results (Table 2) indicated that the azol-2-ylideneamines and the aurated compounds are much less active than chloroquine (reference drug) against $P$. falciparum and, again, that auration increases activity. Significant haemolysis of the host erythrocytes (observed as haemoglobin released into the culture supernatant) was present at concentrations of 510 times higher than the corresponding $\mathrm{IC}_{50} \mathrm{~s}$ of the aurated compounds, suggesting that host cell membrane perturbations may contribute to the antimalarial activity of the compounds.
A comparison with the $\mathrm{IC}_{50}$ results obtained against mammalian cells (Table 2) indicates that the selectivity index (parasite $v s$. mammalian activity) would require significant improvement before these compounds could be considered suitable for further investigation as antimalarials.

\section{Conclusions}

Ylideneamine gold(I) complexes, particularly those that contain trans phosphine ligands, are remarkably air and moisture stable and the $=\mathrm{NH}$ functionality seems completely compatible with these soft metal centres despite the fact that the iso-electronic gold(I)-oxygen bonds are 'intrinsically weak' ${ }^{28}$ and that such complexes with bicovalent oxygen donors (like ketones or phosphineoxides) are not known.

Preliminary screening tests have now indicated that the new heterocyclic ylideneamine gold complexes, although sometimes much more active than the free ligands, do not exhibit exceptional anticancer activity. Further modifications to the ylideneamines or to the ancillary phosphine or NHC ligands that are also present could increase antitumour or antimalarial activity.

\section{Experimental}

\section{General procedures and instruments}

Reactions were carried out under argon using standard Schlenk and vacuum-line techniques. All solvents were predried on ground $\mathrm{KOH}$ or molecular sieves and freshly distilled prior to use. Tetrahydrofuran (THF), $n$-hexane, $n$-pentane and diethyl ether were distilled under $\mathrm{N}_{2}$ from sodium benzophenone ketyl, acetone from $3 \AA$ molecular sieves, dichloromethane and methanol from $\mathrm{CaH}_{2}$ and ethanol from magnesium. Methyliodide, $\mathrm{CF}_{3} \mathrm{SO}_{3} \mathrm{CH}_{3}$, 4-methyl-thiazol-2-ylamine and benzothiazol-2-ylamine were purchased from Aldrich. $1 \mathrm{H}$-benzimidazol-2-ylamine, $\mathrm{AgNO}_{3}$ and $\mathrm{KH}$ were purchased from Fluka. Literature methods were used to prepare $\left[\mathrm{Au}\left(\mathrm{C}_{6} \mathrm{~F}_{5}\right)(\text { tht })\right]^{30}$ from $[\mathrm{Au}(\mathrm{Cl})(\mathrm{tht})]^{31}$ $\left[\mathrm{Au}(\mathrm{Cl})\left(\mathrm{PPh}_{3}\right)\right]^{32}$ from $\left[\mathrm{HAuCl}_{4}\right],^{33} \quad\left[\mathrm{Au}\left(\mathrm{NO}_{3}\right)\left(\mathrm{PPh}_{3}\right)\right]^{17}$ from $\left[\mathrm{Au}(\mathrm{Cl})\left(\mathrm{PPh}_{3}\right)\right]$ and $\left[\mathrm{Au}\left(1,3-{ }^{-} \mathrm{BuIm}-2 \text {-ylidene }\right)\left(\mathrm{NO}_{3}\right)\right]^{18}$ from 1,3${ }^{\mathrm{t}} \mathrm{BuIm} .{ }^{34}\left[\mathrm{Au}(\mathrm{Cl})\left(\mathrm{SMe}_{2}\right)\right]$ was prepared from $\left[\mathrm{HAuCl}_{4}\right]$ following the same method as reported in the literature for the preparation of $[\mathrm{Au}(\mathrm{Cl})(\mathrm{tht})]$.

Melting points were determined on Stuart SMP3 apparatus and are uncorrected. Mass spectra were recorded on an AMD 604 (EI, $70 \mathrm{eV}$ ), VG Quattro (ESI, $70 \mathrm{eV}$ methanol, acetonitrile) or VG 70 SEQ (FAB, $70 \mathrm{eV}$ ) instrument. In the case of EI-MS and FAB-MS the isotopic distribution patterns were checked against the theoretical distribution. NMR spectra were recorded on a Varian 300/400 FT or INOVA $600 \mathrm{MHz}$ spectrometer $\left({ }^{1} \mathrm{H}\right.$ NMR at $300 / 400 / 600 \mathrm{MHz},{ }^{13} \mathrm{C} \mathrm{NMR}$ at $75 / 100 / 150 \mathrm{MHz},{ }^{15} \mathrm{~N} \mathrm{NMR}$ at $60.8 \mathrm{MHz},{ }^{31} \mathrm{P} \mathrm{NMR}$ at $121 / 161 \mathrm{MHz}$ and ${ }^{19} \mathrm{~F} \mathrm{NMR}$ at 376 $\mathrm{MHz}$ ) with the chemical shifts reported relative to TMS with the solvent resonance as internal reference or $\mathrm{NH}_{3} \mathrm{NO}_{2}\left({ }^{15} \mathrm{~N}\right), 85 \%$ $\mathrm{H}_{3} \mathrm{PO}_{4}\left({ }^{31} \mathrm{P}\right)$ or $\mathrm{CFCl}_{3}\left({ }^{19} \mathrm{~F}\right)$ as external reference. Infrared spectra were recorded on a Thermo Nicolet Avatar 330FT-IR with a Smart OMNI ATR (attenuated total reflectance) sampler. Elemental analysis was carried out at the School of Chemistry, University of the Witwatersrand. Prior to elemental analysis, products were evacuated under high vacuum for $10 \mathrm{~h}$. 


\section{Synthesis}

Preparation of 1,3-dimethyl-1,3-dihydro-benzimidazol-2ylideneamine, I. Powdered $\mathrm{KOH}(0.37 \mathrm{~g}, 6.50 \mathrm{mmol})$ was added to a stirring solution of $1 H$-benzimidazol-2-ylamine $(0.43 \mathrm{~g}$, $3.25 \mathrm{mmol})$ in acetone $(13 \mathrm{ml})$. A thick colourless precipitate was visible after $10 \mathrm{~min}$. After the addition of $\mathrm{CH}_{3} \mathrm{I}(0.20 \mathrm{ml}, 0.46 \mathrm{~g}$, $2.25 \mathrm{mmol}$ ) the reaction mixture was stirred vigorously for $10 \mathrm{~min}$ after which the brown solution (with only the excess $\mathrm{KOH}$ still suspended) was transferred to a separating funnel containing benzene $(120 \mathrm{ml})$. The organic layer was washed with water $(1 \times 20 \mathrm{ml})$ and saturated $\mathrm{NaCl}$ solution $(20 \mathrm{ml})$ and subsequently dried over anhydrous $\mathrm{MgSO}_{4}$. The solvent was removed in vacuo and the remaining off-white solid was redissolved in $\mathrm{CH}_{2} \mathrm{Cl}_{2}$ $(30 \mathrm{ml})$. After cooling the solution to $-40{ }^{\circ} \mathrm{C}, \mathrm{CF}_{3} \mathrm{SO}_{3} \mathrm{CH}_{3}$ $(0.37 \mathrm{ml}, 0.53 \mathrm{~g}, 3.25 \mathrm{mmol})$ was added and the reaction mixture stirred at this temperature for $1 \mathrm{~h}$. The mixture was allowed to reach room temperature, whereafter the volatiles were removed in vacuo. The remaining colourless residue was washed with diethyl ether $(2 \times 20 \mathrm{ml})$, dried in vacuo and resuspended in THF $(30 \mathrm{ml})$. KH $(0.13 \mathrm{~g}, 3.25 \mathrm{mmol})$ in THF $(5 \mathrm{ml})$ was added to the stirring suspension. Gas evolution was evident after addition of the KH. The mixture was refluxed for $1 \mathrm{~h}$ during which the colourless suspension cleared up to yield a yellow solution. The solution was stripped of solvent and the solid residue was extracted with $\mathrm{CH}_{2} \mathrm{Cl}_{2}$. The $\mathrm{CH}_{2} \mathrm{Cl}_{2}$ extract was filtered through anhydrous $\mathrm{MgSO}_{4}$ and reduced to dryness to yield the pure product as a colourless microcrystalline solid (0.46 g, 88\%). Colourless crystals of $\mathbf{I}$ were obtained by slow evaporation of a concentrated solution of the compound in $\mathrm{CH}_{2} \mathrm{Cl}_{2}$. $\mathrm{Mp}$ 59-60 ${ }^{\circ} \mathrm{C}$. IR $v_{\max } / \mathrm{cm}^{-1} 3235 \mathrm{~s} v(\mathrm{~N}-\mathrm{H}), 3058 \mathrm{w} v\left(\mathrm{C}_{\text {aryl }}-\mathrm{H}\right), 2931 \mathrm{w}$ $v\left(\mathrm{C}_{\mathrm{sp}}{ }^{3} \mathrm{H}\right), 1625-1608 \mathrm{~s} v(\mathrm{C}=\mathrm{N}), 1500-1392 \mathrm{~s} v\left(\mathrm{C}=\mathrm{C}_{\text {aryl }}\right), 1326 \mathrm{w}$ $v(\mathrm{C}-\mathrm{N}), 724 \mathrm{~s} \delta^{\mathrm{b}}{ }_{\text {oop }}\left(\mathrm{C}_{\text {aryl }}=\mathrm{C}_{\text {aryl }}\right) .{ }^{1} \mathrm{H} \mathrm{NMR}\left(\mathrm{CD}_{2} \mathrm{Cl}_{2}\right): \delta_{\mathrm{H}} 6.96(2 \mathrm{H}$, $\left.\mathrm{dd},{ }^{3} J 5.7 \mathrm{~Hz},{ }^{4} J 3.4 \mathrm{~Hz}, \mathrm{NCCHCH}\right), 6.81\left(2 \mathrm{H}, \mathrm{dd},{ }^{3} J 5.6 \mathrm{~Hz}\right.$, $\left.{ }^{4} \mathrm{~J} 3.4 \mathrm{~Hz}, \mathrm{NCCH}\right), 4.16(1 \mathrm{H}, \mathrm{bs}, \mathrm{NH}), 3.28\left(6 \mathrm{H}, \mathrm{s}, \mathrm{NCH}_{3}\right) .{ }^{13} \mathrm{C}$ NMR $\left(\mathrm{CD}_{2} \mathrm{Cl}_{2}\right): \delta_{\mathrm{C}} 156.3(\mathrm{~s}, \mathrm{NCN}), 133.0(\mathrm{~s}, \mathrm{NCCH}), 120.6$ $(\mathrm{s}, \mathrm{NCCHCH}), 106.2(\mathrm{~s}, \mathrm{NCCH}), 27.7\left(\mathrm{~s}, \mathrm{NCH}_{3}\right) .{ }^{15} \mathrm{~N} \mathrm{NMR}$ $\left(\mathrm{CD}_{2} \mathrm{Cl}_{2}\right): \delta_{\mathrm{N}}-278.0\left(\mathrm{~s}, \mathrm{NCH}_{3}\right) . m / z(\mathrm{FAB}-\mathrm{MS}) 162\left(100, \mathrm{M}^{+}\right)$, $147\left(17,\left(\mathrm{M}-\mathrm{CH}_{3}\right)^{+}\right)$.

Preparation of 3-methyl-3H-benzothiazol-2-ylideneamine, $\$$ II. The alkylating agent, $\mathrm{CF}_{3} \mathrm{SO}_{3} \mathrm{CH}_{3}(0.68 \mathrm{ml}, 1.0 \mathrm{~g}, 6.0 \mathrm{mmol})$, was added dropwise to a solution of benzothiazol-2-ylamine $(0.91 \mathrm{~g}$, $6.0 \mathrm{mmol})$ in diethyl ether $(20 \mathrm{ml})$ at $-40{ }^{\circ} \mathrm{C}$. Upon addition of the $\mathrm{CF}_{3} \mathrm{SO}_{3} \mathrm{CH}_{3}$, a thick colourless precipitate formed. The reaction mixture was allowed to stir at this temperature for $1 \mathrm{~h}$ and then to slowly reach room temperature. The solvents and other volatiles were removed in vacuo and the resulting colourless solid was washed with diethyl ether $(2 \times 40 \mathrm{ml})$, dried in vacuo, and resuspended in THF $(20 \mathrm{ml})$. A suspension of $\mathrm{KH}(0.24 \mathrm{~g}$, $6.03 \mathrm{mmol})$ in THF $(5 \mathrm{ml})$ was added to the stirring mixture. The liberation of hydrogen gas could be observed by the formation of bubbles. The mixture was refluxed for $1 \mathrm{~h}$, during which time the colourless suspension cleared up to yield a yellow solution. The solution was reduced to dryness and the solid residue was extracted with $\mathrm{CH}_{2} \mathrm{Cl}_{2}$. The $\mathrm{CH}_{2} \mathrm{Cl}_{2}$ extract was subsequently filtered through anhydrous $\mathrm{MgSO}_{4}$. After removal of the solvent

$\$$ Caution: 3-methyl-3H-benzothiazol-2-ylideneamine may irritate respiratory tracts when inhaled. by evaporation under vacuum the pure product was obtained as a yellow solid $(0.79 \mathrm{~g}, 79 \%)$. Mp $112-114{ }^{\circ} \mathrm{C}$. IR $v_{\max } / \mathrm{cm}^{-1}$ 3243 s $v(\mathrm{~N}-\mathrm{H}), 3047 \mathrm{w} v\left(\mathrm{C}_{\text {aryl }}-\mathrm{H}\right), 2931 \mathrm{w} v\left(\mathrm{C}_{\mathrm{sp}^{3}}-\mathrm{H}\right), 1596-$ $1574 \mathrm{~s} v(\mathrm{C}=\mathrm{N}), 1474-1417 \mathrm{~s} v\left(\mathrm{C}=\mathrm{C}_{\text {aryl }}\right), 1330 \mathrm{~m} v(\mathrm{C}-\mathrm{N}), 736 \mathrm{~s}$ $\delta^{\mathrm{b}}{ }_{\text {oop }}\left(\mathrm{C}_{\text {aryl }}=\mathrm{C}_{\text {aryl }}\right) .{ }^{1} \mathrm{H} \mathrm{NMR}\left(\mathrm{CD}_{2} \mathrm{Cl}_{2}\right): \delta_{\mathrm{H}} 7.26\left(1 \mathrm{H}, \mathrm{ddd},{ }^{3} J 7.7 \mathrm{~Hz}\right.$, $\left.{ }^{4} J 1.4 \mathrm{~Hz},{ }^{5} J 0.5 \mathrm{~Hz}, \mathrm{NCCH}\right), 7.24\left(1 \mathrm{H}, \mathrm{td},{ }^{3} J 7.8 \mathrm{~Hz},{ }^{4} J 1.4 \mathrm{~Hz}\right.$, $\mathrm{NCCHCH}), 7.00\left(1 \mathrm{H}, \mathrm{td},{ }^{3} J 7.8 \mathrm{~Hz},{ }^{4} J 1.3 \mathrm{~Hz}, \mathrm{SCCHCH}\right), 6.86$ $\left(1 \mathrm{H}, \mathrm{dm},{ }^{3} J 8.5 \mathrm{~Hz}, \mathrm{SCCH}\right), 4.95(1 \mathrm{H}, \mathrm{bs}, \mathrm{NH}), 3.37 \mathrm{~Hz}(3 \mathrm{H}, \mathrm{s}$, $\left.\mathrm{NCH}_{3}\right) .{ }^{13} \mathrm{C} \mathrm{NMR}\left(\mathrm{CD}_{2} \mathrm{Cl}_{2}\right): \delta_{\mathrm{C}} 162.7$ (s, NCS), $142.0(\mathrm{~s}, \mathrm{NCCH})$, 126.8 (s, NCCH), 123.2 (s, NCCHCH), 122.1 (s, SCCHCH), 121.9 (s, SCCH), 109.7 (s, SCCH), 29.4 (s, $\mathrm{NCH}_{3}$ ). m/z (FAB-MS) 165 $\left(100, \mathrm{M}^{+}\right), 150\left(6,\left(\mathrm{M}-\mathrm{CH}_{3}\right)^{+}\right)$.

Preparation of 3,4-dimethyl-3H-thiazol-2-ylideneamine, III. Compound III was prepared by the same method as that described for II with $\mathrm{CF}_{3} \mathrm{SO}_{3} \mathrm{CH}_{3}(1.13 \mathrm{ml}, 1.64 \mathrm{~g}, 10.0 \mathrm{mmol})$, 4-methylthiazol-2-ylamine $(1.14 \mathrm{~g}, 10.0 \mathrm{mmol})$ and $\mathrm{KH}(0.40 \mathrm{~g}, 10 \mathrm{mmol})$. After removal of the solvent by evaporation under vacuum, the crude product was sublimed under vacuum $(0.1 \mathrm{mbar})$ at $75^{\circ} \mathrm{C}$ to achieve the pure product as a colourless crystalline solid $(0.79 \mathrm{~g}$, $62 \%$ ). Colourless crystals of III were obtained by slow evaporation of a concentrated solution of the compound in $\mathrm{CH}_{2} \mathrm{Cl}_{2}$. Mp 46$48{ }^{\circ} \mathrm{C}$. IR $v_{\max } / \mathrm{cm}^{-1} 3239 \mathrm{w} v(\mathrm{~N}-\mathrm{H}), 3062 \mathrm{w} v\left(\mathrm{C}_{\text {aryl }}-\mathrm{H}\right), 2916$ $\mathrm{W} v\left(\mathrm{C}_{\mathrm{sp}}{ }^{3}-\mathrm{H}\right), 1606-1564 \mathrm{~s} v(\mathrm{C}=\mathrm{N}), 1418-1364 \mathrm{~s} v\left(\mathrm{C}=\mathrm{C}_{\text {aryl }}\right) .{ }^{1} \mathrm{H}$ NMR $\left(\mathrm{CD}_{2} \mathrm{Cl}_{2}\right): \delta_{\mathrm{H}} 5.47(1 \mathrm{H}, \mathrm{bs}, \mathrm{NH}), 5.46\left(1 \mathrm{H}, \mathrm{q},{ }^{4} J 1.4 \mathrm{~Hz}\right.$, $\mathrm{SCH}), 3.17\left(3 \mathrm{H}, \mathrm{s}, \mathrm{NCH}_{3}\right), 2.01\left(3 \mathrm{H}, \mathrm{s},{ }^{4} \mathrm{~J} 1.4 \mathrm{~Hz}, \mathrm{CCH}_{3}\right) .{ }^{13} \mathrm{C}$ $\mathrm{NMR}\left(\mathrm{CD}_{2} \mathrm{Cl}_{2}\right): \delta_{\mathrm{C}} 166.6(\mathrm{~s}, \mathrm{NCS}), 136.0\left(\mathrm{~s}, \mathrm{NCCH}_{3}\right), 92.3$ (s, $\left.\mathrm{SCC}\left(\mathrm{CH}_{3}\right) \mathrm{N}\right), 30.0\left(\mathrm{~s}, \mathrm{NCH}_{3}\right), 14.9\left(\mathrm{~s}, \mathrm{CCH}_{3}\right) . m / z$ (FAB-MS) $128\left(90, \mathrm{M}^{+}\right), 113\left(15,\left(\mathrm{M}-\mathrm{CH}_{3}\right)^{+}\right), 100\left(27,\left(\mathrm{M}-\mathrm{NCH}_{3}\right)^{+}\right), 86(25$, $\left.\left(\mathrm{M}-\mathrm{CH}_{3}-\mathrm{NH}\right)^{+}\right), 56\left(100,\left(\mathrm{CH}_{3} \mathrm{NC}=\mathrm{NH}\right)^{+}\right)$.

Preparation of 1,3-dimethyl-1,3-dihydro-benzimidazol-2ylideneamine(pentafluorophenyl)gold(I), 1. A solution of $\left[\mathrm{Au}\left(\mathrm{C}_{6} \mathrm{~F}_{5}\right)(\mathrm{tht})\right](0.32 \mathrm{~g}, 0.70 \mathrm{mmol})$ in THF $(10 \mathrm{ml})$ was transferred to a Schlenk tube containing $\mathbf{I}(0.11 \mathrm{~g}, 0.70 \mathrm{mmol})$ dissolved in THF $(20 \mathrm{ml})$. The reaction mixture was allowed to stir for three days at room temperature, during which minor decomposition occurred. The resulting yellow solution was filtered to remove colloidal gold deposits, and subsequently reduced to dryness in vacuo. The remaining residue was washed with diethyl ether $(2 \times 30 \mathrm{ml})$ and dried to yield the pure product as a colourless solid (0.26 g, 70\%). Mp 94-100 ${ }^{\circ} \mathrm{C}$. Found: C, 34.8; $\mathrm{H}, 2.3 ; \mathrm{N}, 7.7 . \mathrm{C}_{15} \mathrm{H}_{11} \mathrm{AuF}_{5} \mathrm{~N}_{3}$ requires $\mathrm{C}, 34.3 ; \mathrm{H}, 2.1 ; \mathrm{N}, 8.0 \%$. IR $v_{\max } / \mathrm{cm}^{-1} 3399 \mathrm{~s} v(\mathrm{~N}-\mathrm{H}), 3174 \mathrm{w} v(\mathrm{C}-\mathrm{H}), 1624 \mathrm{~s} v(\mathrm{C}=\mathrm{N})$, $1498-1450 \mathrm{~s} v\left(\mathrm{C}=\mathrm{C}_{\text {aryl }}\right), 1436 \mathrm{~m} v(\mathrm{C}-\mathrm{N}), 1498 \mathrm{~s}, 1058 \mathrm{~m}, 946 \mathrm{~s}$ and $799 \mathrm{~s} v\left(\mathrm{C}_{6} \mathrm{~F}_{5}\right)$ and $\delta^{\mathrm{b}}\left(\mathrm{C}_{6} \mathrm{~F}_{5}\right) .{ }^{1} \mathrm{H} \mathrm{NMR}\left(\mathrm{CD}_{2} \mathrm{Cl}_{2}\right): \delta_{\mathrm{H}} 8.43(1 \mathrm{H}$, bs, NH), $7.47\left(2 \mathrm{H}, \mathrm{dd},{ }^{1} J 5.9 \mathrm{~Hz},{ }^{2} J 3.4 \mathrm{~Hz}, \mathrm{NCCHCH}\right), 7.32$ $\left(2 \mathrm{H}, \mathrm{dd},{ }^{3} J 5.9 \mathrm{~Hz},{ }^{4} J 3.4 \mathrm{~Hz}, \mathrm{NCCH}\right), 3.73\left(6 \mathrm{H}, \mathrm{s}, \mathrm{NCH}_{3}\right) .{ }^{13} \mathrm{C}$ $\operatorname{NMR}\left(\mathrm{CD}_{2} \mathrm{Cl}_{2}\right): \delta_{\mathrm{C}} 156.4(\mathrm{~s}, \mathrm{NCN}), 148.6\left(\mathrm{ddm},{ }^{1} J 228.3 \mathrm{~Hz}\right.$, $\left.{ }^{2} J 26.9 \mathrm{~Hz}, o-\mathrm{C}_{6} \mathrm{~F}_{5}\right), 138.5\left(\mathrm{dm},{ }^{1} J 248.5 \mathrm{~Hz}, p-\mathrm{C}_{6} \mathrm{~F}_{5}\right), 137.3$ $\left(\mathrm{dm},{ }^{1} J 226.5 \mathrm{~Hz}, m-\mathrm{C}_{6} \mathrm{~F}_{5}\right), 131.4(\mathrm{~s}, \mathrm{NCCH}), 126.1\left(\mathrm{tm},{ }^{2} J\right.$ $57.3 \mathrm{~Hz}, i-\mathrm{C}_{6} \mathrm{~F}_{5}$ ), $124.4(\mathrm{~s}, \mathrm{NCCHCH}), 110.5(\mathrm{~s}, \mathrm{NCCH}), 39.2(\mathrm{~s}$, $\left.\mathrm{NCH}_{3}\right) \cdot{ }^{19} \mathrm{~F}$ NMR $\left(\mathrm{CD}_{2} \mathrm{Cl}_{2}\right): \delta_{\mathrm{F}}-164.3\left(\mathrm{~m}, p-\mathrm{C}_{6} \mathrm{~F}_{5}\right),-161.1\left(\mathrm{t},{ }^{3} J\right.$ $\left.19.6 \mathrm{~Hz}, m-\mathrm{C}_{6} \mathrm{~F}_{5}\right),-116.6\left(\mathrm{~m}, o-\mathrm{C}_{6} \mathrm{~F}_{5}\right) . m / z$ (FAB-MS) $511(11$, $\left.\left(\mathrm{M}-\mathrm{CH}_{3}\right)^{+}\right), 355\left(28,\left(\mathrm{M}-\mathrm{C}_{6} \mathrm{~F}_{5}\right)^{+}\right), 162\left(89,\left(\mathrm{M}-\mathrm{AuC}_{6} \mathrm{~F}_{5}\right)^{+}\right), 147$ $\left(46,\left(\mathrm{M}-\mathrm{AuC}_{6} \mathrm{~F}_{5}-\mathrm{CH}_{3}\right)^{+}\right)$.

Preparation of 3-methyl-3 $\boldsymbol{H}$-benzothiazol-2-ylideneamine(pentafluorophenyl)gold(I), 2. A solution of freshly prepared $\left[\mathrm{Au}\left(\mathrm{C}_{6} \mathrm{~F}_{5}\right)(\mathrm{tht})\right](0.22 \mathrm{~g}, 0.48 \mathrm{mmol})$ in THF $(10 \mathrm{ml})$ was 
transferred to a Schlenk tube containing II $(0.08 \mathrm{~g}, 0.49 \mathrm{mmol})$ dissolved in THF $(20 \mathrm{ml})$. Minor decomposition occurred after the addition and the solution was therefore filtered to remove colloidal gold, and transferred into a clean reaction vessel. The reaction mixture was allowed to stir for three days at room temperature. Further decomposition occurred during this stirring period and the resulting solution was therefore filtered through anhydrous $\mathrm{MgSO}_{4}$ and reduced to dryness in vacuo to yield the title compound as a colourless solid $(0.20 \mathrm{~g}, 78 \%)$. Mp 128-132 ${ }^{\circ} \mathrm{C}$. Found: $\mathrm{C}, 32.0 ; \mathrm{H}, 1.6 ; \mathrm{N}, 5.1 . \mathrm{C}_{14} \mathrm{H}_{8} \mathrm{AuF}_{5} \mathrm{~N}_{2} \mathrm{~S}$ requires $\mathrm{C}, 31.8 ; \mathrm{H}, 1.5 ; \mathrm{N}, 5.3 \%$. IR $v_{\max } / \mathrm{cm}^{-1} 3375 \mathrm{~m} v(\mathrm{~N}-\mathrm{H})$, $2960 \mathrm{w} v(\mathrm{C}-\mathrm{H}), 1569 \mathrm{~s} v(\mathrm{C}=\mathrm{N}), 1477-1453 \mathrm{~s} v\left(\mathrm{C}=\mathrm{C}_{\text {ary }}\right), 1438 \mathrm{~m}$ $v(\mathrm{C}-\mathrm{N}), 1501 \mathrm{~s}, 1058 \mathrm{~m}, 950 \mathrm{~s}$ and $801 \mathrm{~s} v\left(\mathrm{C}_{6} \mathrm{~F}_{5}\right)$ and $\delta^{\mathrm{b}}\left(\mathrm{C}_{6} \mathrm{~F}_{5}\right) .{ }^{1} \mathrm{H}$ $\operatorname{NMR}\left(\mathrm{CD}_{2} \mathrm{Cl}_{2}\right): \delta_{\mathrm{H}} 7.72(1 \mathrm{H}, \mathrm{bs}, \mathrm{NH}), 7.56\left(1 \mathrm{H}, \mathrm{dm},{ }^{3} J 7.8 \mathrm{~Hz}\right.$, $\mathrm{NCC} H), 7.36\left(1 \mathrm{H}, \mathrm{td},{ }^{3} J 8.4 \mathrm{~Hz},{ }^{4} J 1.1 \mathrm{~Hz}, \mathrm{NCCHCH}\right), 7.23$ $\left(1 \mathrm{H}, \mathrm{d},{ }^{3} J 8.0 \mathrm{~Hz}, \mathrm{SCC} H\right), 7.17\left(1 \mathrm{H}, \mathrm{td},{ }^{3} J 7.7 \mathrm{~Hz},{ }^{4} J 1.0 \mathrm{~Hz}\right.$, $\mathrm{SCCHCH}), 3.55\left(3 \mathrm{H}, \mathrm{s}, \mathrm{NCH}_{3}\right),{ }^{13} \mathrm{C} \mathrm{NMR}\left(\mathrm{CD}_{2} \mathrm{Cl}_{2}\right): \delta_{\mathrm{C}} 173.1$ (s, NCS), $150.1\left(\mathrm{ddm},{ }^{1} J 226.3 \mathrm{~Hz},{ }^{2} J 23.9 \mathrm{~Hz}, o-\mathrm{C}_{6} \mathrm{~F}_{5}\right.$ ), 141.8 $(\mathrm{s}, \mathrm{NCCH}), 138.7\left(\mathrm{dm},{ }^{1} J 244.0 \mathrm{~Hz}, p-\mathrm{C}_{6} \mathrm{~F}_{5}\right), 137.4\left(\mathrm{dm},{ }^{1} J\right.$ $247.7 \mathrm{~Hz}, m-\mathrm{C}_{6} \mathrm{~F}_{5}$ ), 127.6 (s, NCCH), 124.4 (s, SCCH), 123.0 (s, $\mathrm{NCCHCH}), 122.6(\mathrm{~s}, \mathrm{SCCHCH}), 118.4\left(\mathrm{tm},{ }^{2} J 57.6 \mathrm{~Hz}, i-\mathrm{C}_{6} \mathrm{~F}_{5}\right)$, $111.6(\mathrm{~s}, \mathrm{SCCH}), 30.1\left(\mathrm{~s}, \mathrm{NCH}_{3}\right) .{ }^{19} \mathrm{~F} \mathrm{NMR}\left(\mathrm{CD}_{2} \mathrm{Cl}_{2}\right): \delta_{\mathrm{F}}-165.3$ $\left(\mathrm{m}, p-\mathrm{C}_{6} \mathrm{~F}_{5}\right),-163.1\left(\mathrm{tt},{ }^{3} \mathrm{~J} 5.3 \mathrm{~Hz},{ }^{4} J 0.5 \mathrm{~Hz}, m-\mathrm{C}_{6} \mathrm{~F}_{5}\right),-116.6(\mathrm{~m}$, $\left.o-\mathrm{C}_{6} \mathrm{~F}_{5}\right) . m / z\left(\right.$ FAB-MS) $528\left(8, \mathrm{M}^{+}\right), 514\left(3,\left(\mathrm{M}-\mathrm{CH}_{3}\right)^{+}\right), 361(4$, $\left.\left(\mathrm{M}-\mathrm{C}_{6} \mathrm{~F}_{5}\right)^{+}\right), 165\left(73,\left(\mathrm{M}-\mathrm{AuC}_{6} \mathrm{~F}_{5}\right)^{+}\right)$.

Preparation of 3,4-dimethyl-3 $\mathrm{H}$-thiazol-2-ylideneamine(pentafluorophenyl)gold(I), 3. A solution of freshly prepared $\left[\mathrm{Au}\left(\mathrm{C}_{6} \mathrm{~F}_{5}\right)(\mathrm{tht})\right](0.30 \mathrm{~g}, 0.67 \mathrm{mmol})$ in THF $(10 \mathrm{ml})$ was transferred to a Schlenk tube containing III $(0.09 \mathrm{~g}, 0.79 \mathrm{mmol})$ dissolved in THF $(30 \mathrm{ml})$. The reaction mixture was allowed to stir for four days at room temperature. Slight decomposition occurred during this stirring period and the reaction mixture was filtered through anhydrous $\mathrm{Na}_{2} \mathrm{SO}_{4}$ and reduced to dryness in vacuo. The crude product was washed with diethyl ether $(2 \times$ $20 \mathrm{ml})$ and dried under vacuum to yield the title compound as an off-white solid $(0.31 \mathrm{~g}, 93 \%)$. Mp $100-106{ }^{\circ} \mathrm{C}$. Found: C, 26.2; $\mathrm{H}, 1.4 ; \mathrm{N}, 5.4 . \mathrm{C}_{5} \mathrm{H}_{8} \mathrm{AuF}_{5} \mathrm{~N}_{2} \mathrm{~S}$ requires $\mathrm{C}, 26.8 ; \mathrm{H}, 1.6 ; \mathrm{N}, 5.7 \%$. IR $v_{\max } / \mathrm{cm}^{-1} 3379 \mathrm{~s} v(\mathrm{~N}-\mathrm{H}), 3107 \mathrm{w} v(\mathrm{C}-\mathrm{H}), 1554 \mathrm{~s} v(\mathrm{C}=\mathrm{N})$, $1499-1437 \mathrm{~s} v\left(\mathrm{C}=\mathrm{C}_{\text {aryl }}\right), 1435 \mathrm{~s} v(\mathrm{CN}), 1499 \mathrm{~s}, 1060 \mathrm{~m}, 949 \mathrm{~s}$ and $800 \mathrm{~s} v\left(\mathrm{C}_{6} \mathrm{~F}_{5}\right)$ and $\delta^{b}\left(\mathrm{C}_{6} \mathrm{~F}_{5}\right) .{ }^{1} \mathrm{H}$ NMR $\left(\mathrm{CD}_{2} \mathrm{Cl}_{2}\right): \delta_{\mathrm{H}} 6.92(1 \mathrm{H}$, bs, $\mathrm{NH}), 6.12(1 \mathrm{H}, \mathrm{bs}, \mathrm{SCCH}), 3.47\left(3 \mathrm{H}, \mathrm{s}, \mathrm{NCH}_{3}\right), 2.24(3 \mathrm{H}, \mathrm{d}$, $\left.{ }^{4} J 1.2 \mathrm{~Hz}, \mathrm{CCH}_{3}\right) .{ }^{13} \mathrm{C} \mathrm{NMR}\left(\mathrm{CD}_{2} \mathrm{Cl}_{2}\right): \delta_{\mathrm{C}} 176.1(\mathrm{~s}, \mathrm{NCS}), 150.1$ $\left(\mathrm{ddm},{ }^{1} J 226.8 \mathrm{~Hz},{ }^{2} J 24.5 \mathrm{~Hz}, o-\mathrm{C}_{6} \mathrm{~F}_{5}\right), 139.3\left(\mathrm{dm},{ }^{1} J 248.7 \mathrm{~Hz}\right.$, $\left.m-\mathrm{C}_{6} \mathrm{~F}_{5}\right), 139.2(\mathrm{~s}, \mathrm{NCC}), 138.0\left(\mathrm{dm},{ }^{1} J 243.1 \mathrm{~Hz}, p-\mathrm{C}_{6} \mathrm{~F}_{5}\right), 97.5$ (s, $\mathrm{SCCH}), 27.1\left(\mathrm{~s}, \mathrm{NCH}_{3}\right), 15.8\left(\mathrm{~s}, \mathrm{CCH}_{3}\right) .{ }^{19} \mathrm{~F}$ NMR $\left(\mathrm{CD}_{2} \mathrm{Cl}_{2}\right)$ : $\delta_{\mathrm{F}}-169.8\left(\mathrm{~m}, p-\mathrm{C}_{6} \mathrm{~F}_{5}\right),-167.7\left(\mathrm{t},{ }^{3} J 19.6 \mathrm{~Hz}, m-\mathrm{C}_{6} \mathrm{~F}_{5}\right),-121.2(\mathrm{~m}$, $\left.o-\mathrm{C}_{6} \mathrm{~F}_{5}\right)$.

Preparation of 1,3-dimethyl-1,3-dihydro-benzimidazol-2ylideneamine(triphenylphosphine)gold(I) nitrate, 4 . A suspension of $\left[\mathrm{Au}\left(\mathrm{NO}_{3}\right)\left(\mathrm{PPh}_{3}\right)\right](0.45 \mathrm{~g}, 0.81 \mathrm{mmol})$ in diethyl ether $(10 \mathrm{ml})$ was added to a stirring solution of $\mathbf{I}(0.13 \mathrm{~g}, 0.83 \mathrm{mmol})$ in diethyl ether $(20 \mathrm{ml})$. The reaction mixture was allowed to stir for three days at room temperature. During this period, the light yellow solution became colourless and a new suspension formed. The mixture was filtered, the remaining solid washed with diethyl ether $(2 \times 20 \mathrm{ml})$, extracted with $\mathrm{CH}_{2} \mathrm{Cl}_{2}$ and reduced to dryness in vacuo to yield the pure product as a colourless solid $(0.49 \mathrm{~g}$,
87.9\%). Mp 126-128 (decomp. $)^{\circ} \mathrm{C}$. Found: C, 47.3; H, 3.9; N, 8.4. $\mathrm{C}_{27} \mathrm{H}_{26} \mathrm{AuN}_{4} \mathrm{O}_{3} \mathrm{P}$ requires $\mathrm{C}, 47.5 ; \mathrm{H}, 3.8 ; \mathrm{N}, 8.2 \%$. IR $v_{\max } / \mathrm{cm}^{-1}$ $3249 \mathrm{w} v(\mathrm{~N}-\mathrm{H}), 3048 \mathrm{w} v\left(\mathrm{C}_{\text {aryl }}-\mathrm{H}\right), 1605 \mathrm{~s} v(\mathrm{C}=\mathrm{N}), 1496-1435$ $\mathrm{m} v\left(\mathrm{C}=\mathrm{C}_{\text {aryl }}\right), 743 \mathrm{~m} v(\mathrm{C}=\mathrm{C}) .{ }^{1} \mathrm{H}$ NMR $\left(\mathrm{CD}_{2} \mathrm{Cl}_{2}\right): \delta_{\mathrm{H}} 7.61-7.52$ $(15 \mathrm{H}, \mathrm{m}, \mathrm{PPh}), 7.20\left(2 \mathrm{H}, \mathrm{dd},{ }^{3} J 5.8 \mathrm{~Hz},{ }^{4} J 3.1 \mathrm{~Hz}, \mathrm{NCCHCH}\right)$, $7.12\left(2 \mathrm{H}, \mathrm{dd},{ }^{3} J 5.7 \mathrm{~Hz},{ }^{4} J 3.1 \mathrm{~Hz}, \mathrm{NCCH}\right), 3.76\left(6 \mathrm{H}, \mathrm{s}, \mathrm{NCH}_{3}\right)$, $1.82(1 \mathrm{H}$, bs, $\mathrm{NH}) .{ }^{13} \mathrm{C} \mathrm{NMR}\left(\mathrm{CD}_{2} \mathrm{Cl}_{2}\right): \delta_{\mathrm{C}} 156.3(\mathrm{~s}, \mathrm{NCN})$, $134.4\left(\mathrm{~d},{ }^{2} J 13.7 \mathrm{~Hz}, o-\mathrm{PC}_{6} \mathrm{H}_{5}\right), 132.4\left(\mathrm{~d},{ }^{4} J 2.6 \mathrm{~Hz}, p-\mathrm{PC}_{6} \mathrm{H}_{5}\right)$, 131.2 (s, NCCH), 129.7 (d, $\left.{ }^{3} J 12.0 \mathrm{~Hz}, m-\mathrm{PC}_{6} \mathrm{H}_{5}\right), 128.7$ (d, ${ }^{1} J$ $\left.63.1 \mathrm{~Hz}, i-\mathrm{PC}_{6} \mathrm{H}_{5}\right), 122.9(\mathrm{~s}, \mathrm{NCCHCH}), 108.7(\mathrm{~s}, \mathrm{NCCH}), 30.0(\mathrm{~s}$, $\left.\mathrm{NCH}_{3}\right) \cdot{ }^{31} \mathrm{P} \mathrm{NMR}\left(\mathrm{CD}_{2} \mathrm{Cl}_{2}\right): \delta_{\mathrm{P}} 32.0(\mathrm{~s}) .{ }^{15} \mathrm{~N} \mathrm{NMR}\left(\mathrm{CD}_{2} \mathrm{Cl}_{2}\right): \delta_{\mathrm{N}}$ $-270.7\left(\mathrm{~s}, \mathrm{NCH}_{3}\right) . m / z$ (FAB-MS) $720\left(12, \mathrm{Au}\left(\mathrm{PPh}_{3}\right)_{2}{ }^{+}\right), 620(87$, $\left.\left(\mathrm{M}-\mathrm{NO}_{3}\right)^{+}\right), 606\left(5,\left(\mathrm{M}-\mathrm{NO}_{3}-\mathrm{CH}_{3}\right)^{+}\right), 543\left(4,\left(\mathrm{M}-\mathrm{NO}_{3}-\mathrm{Ph}\right)^{+}\right)$, $459\left(25, \mathrm{AuPPh}_{3}{ }^{+}\right), 162\left(95,\left(\mathrm{M}-\mathrm{NO}_{3}-\mathrm{AuPPh}_{3}\right)^{+}\right)$.

Preparation of 3-methyl-3H-benzothiazol-2-ylideneamine(triphenylphosphine)gold(I) nitrate, 5. A suspension of $\left[\mathrm{Au}\left(\mathrm{NO}_{3}\right)\left(\mathrm{PPh}_{3}\right)\right](0.45 \mathrm{~g}, 0.81 \mathrm{mmol})$ in diethyl ether $(10 \mathrm{ml})$ was added to a stirring solution of II $(0.14 \mathrm{~g}, 0.82 \mathrm{mmol})$ in diethyl ether $(20 \mathrm{ml})$. The reaction mixture was allowed to stir for three days at room temperature. During this period, the yellow solution had become colourless and a new suspension was visible. The mixture was filtered, the remaining solid washed with diethyl ether $(2 \times 20 \mathrm{ml})$ and dried in vacuo to yield the pure product as a colourless solid $(0.50 \mathrm{~g}, 89 \%)$. Mp $130-135^{\circ} \mathrm{C}$. Found: C, 45.9; $\mathrm{H}, 3.5 ; \mathrm{N}, 6.2 . \mathrm{C}_{26} \mathrm{H}_{23} \mathrm{AuN}_{3} \mathrm{O}_{3} \mathrm{PS}$ requires $\mathrm{C}, 45.6 ; \mathrm{H}, 3.4 ; \mathrm{N}, 6.1 \%$. IR $v_{\max } / \mathrm{cm}^{-1} 3165 \mathrm{w} v(\mathrm{~N}-\mathrm{H}), 3059 \mathrm{w} v\left(\mathrm{C}_{\text {aryl }}-\mathrm{H}\right), 1598-1577 \mathrm{~s}$ $v(\mathrm{C}=\mathrm{N}), 1477-1434 \mathrm{~m} v\left(\mathrm{C}=\mathrm{C}_{\text {aryl }}\right), 746 \mathrm{~m} v(\mathrm{C}=\mathrm{C}) .{ }^{1} \mathrm{H}$ NMR $\left(\mathrm{CD}_{2} \mathrm{Cl}_{2}\right): \delta_{\mathrm{H}} 9.15(1 \mathrm{H}, \mathrm{bs}, \mathrm{NH}), 7.60-7.52(15 \mathrm{H}, \mathrm{m}, \mathrm{PPh}), 7.47$ $\left(1 \mathrm{H}, \mathrm{d},{ }^{3} J 7.8 \mathrm{~Hz}, \mathrm{NCCH}\right), 7.42\left(1 \mathrm{H}, \mathrm{t},{ }^{3} J 8.5 \mathrm{~Hz},{ }^{4} J 1.1 \mathrm{~Hz}\right.$, $\mathrm{NCCHCH}), 7.23\left(1 \mathrm{H}, \mathrm{t},{ }^{3} J 7.8 \mathrm{~Hz}, \mathrm{SCCHCH}\right), 7.14\left(1 \mathrm{H}, \mathrm{d},{ }^{3} J\right.$ $8.0 \mathrm{~Hz}, \mathrm{SCC} H), 3.69\left(3 \mathrm{H}, \mathrm{s}, \mathrm{NCH}_{3}\right) \cdot{ }^{13} \mathrm{C} \mathrm{NMR}\left(\mathrm{CD}_{2} \mathrm{Cl}_{2}\right): \delta_{\mathrm{C}} 172.4$ (s, NCS), 141.1 (s, NCCH), $134.5\left(\mathrm{~d},{ }^{2} J 13.3 \mathrm{~Hz}, o-\mathrm{PC}_{6} \mathrm{H}_{5}\right), 132.6$ (d, ${ }^{4} J 2.6 \mathrm{~Hz}, p-\mathrm{PC}_{6} \mathrm{H}_{5}$ ), 129.7 (d, $\left.{ }^{3} J 12.0 \mathrm{~Hz}, m-\mathrm{PC}_{6} \mathrm{H}_{5}\right), 128.3$ $\left(\mathrm{d},{ }^{1} J 63.6 \mathrm{~Hz}, i-\mathrm{PC}_{6} \mathrm{H}_{5}\right), 127.7(\mathrm{~s}, \mathrm{NCCH}) 124.6(\mathrm{~s}, \mathrm{NCCHCH})$, 122.4 (s, SCCH), 122.4 (s, SCCHCH), 111.8 (s, SCCH), 31.2 (s, $\left.\mathrm{NCH}_{3}\right) \cdot{ }^{31} \mathrm{P}$ NMR $\left(\mathrm{CD}_{2} \mathrm{Cl}_{2}\right): \delta_{\mathrm{P}} 27.7$ (s). $\mathrm{m} / z$ (FAB-MS) $720(9$, $\left.\mathrm{Au}\left(\mathrm{PPh}_{3}\right)_{2}{ }^{+}\right), 623\left(100,\left(\mathrm{M}-\mathrm{NO}_{3}\right)^{+}\right), 459\left(6, \mathrm{AuPPh}_{3}{ }^{+}\right), 164$ (34, $\left.\left(\mathrm{M}-\mathrm{NO}_{3}-\mathrm{AuPPh}_{3}\right)^{+}\right)$.

Preparation of 3,4-dimethyl-3H-thiazol-2-ylideneamine(triphenylphosphine)gold(I) nitrate, 6. A suspension of $\left[\mathrm{Au}\left(\mathrm{NO}_{3}\right)\left(\mathrm{PPh}_{3}\right)\right](0.36 \mathrm{~g}, 0.69 \mathrm{mmol})$ in diethyl ether $(10 \mathrm{ml})$ was added to a stirring solution of III $(0.09 \mathrm{~g}, 0.69 \mathrm{mmol})$ in diethyl ether $(10 \mathrm{ml})$. The reaction mixture was allowed to stir for two days at room temperature. During this period, the yellow solution had become colourless and a new suspension formed. The mixture was filtered, the remaining solid washed with diethyl ether $(2 \times 20 \mathrm{ml})$ and dried in vacuo to yield the pure product as a colourless solid $(0.38 \mathrm{~g}, 84 \%) .{ }^{35} \mathrm{Mp} 95-100{ }^{\circ} \mathrm{C}$. Found: $\mathrm{C}$, $42.4 ; \mathrm{H}, 3.5 ; \mathrm{N}, 6.6 . \mathrm{C}_{23} \mathrm{H}_{23} \mathrm{AuN}_{3} \mathrm{O}_{3}$ PS requires $\mathrm{C}, 42.5 ; \mathrm{H}, 3.6 ; \mathrm{N}$, $6.5 \% . v_{\max } / \mathrm{cm}^{-1} 3186 \mathrm{w} v(\mathrm{~N}-\mathrm{H}), 1545 \mathrm{~s} v(\mathrm{C}=\mathrm{N}), 1478-1434 \mathrm{~m}$ $v\left(\mathrm{C}=\mathrm{C}_{\text {aryl }}\right), 750 \mathrm{~m} v(\mathrm{C}=\mathrm{C}) .{ }^{1} \mathrm{H}$ NMR $\left(\mathrm{CD}_{2} \mathrm{Cl}_{2}\right): \delta_{\mathrm{H}} 8.34(1 \mathrm{H}, \mathrm{bs}$, $\mathrm{NH}), 7.59-7.47(15 \mathrm{H}, \mathrm{m}, \mathrm{PPh}), 5.84(1 \mathrm{H}, \mathrm{bs}, \mathrm{SCH}), 3.48(3 \mathrm{H}, \mathrm{s}$, $\left.\mathrm{NCH}_{3}\right) 2.14\left(3 \mathrm{H}, \mathrm{d},{ }^{4} J 1.0 \mathrm{~Hz}, \mathrm{CCH}_{3}\right) \cdot{ }^{13} \mathrm{C} \mathrm{NMR}\left(\mathrm{CD}_{2} \mathrm{Cl}_{2}\right): \delta_{\mathrm{C}}$ 174.5 (s, NCS), 137.6 (s, $\mathrm{NCCH}_{3}$ ), $134.4\left(\mathrm{~d},{ }^{2} J 13.7 \mathrm{~Hz}, o-\mathrm{PC}_{6} \mathrm{H}_{5}\right.$ ),

$\S$ Note: Product undergoes a colour change when dissolved in chlorinated solvents. It may be sensitive towards oxidation; see ref. 35 . 
$132.5\left(\mathrm{~d},{ }^{4} J 2.6 \mathrm{~Hz}, p-\mathrm{PC}_{6} \mathrm{H}_{5}\right), 129.7\left(\mathrm{~d},{ }^{3} J 12.0 \mathrm{~Hz}, m-\mathrm{PC}_{6} \mathrm{H}_{5}\right)$, $128.3\left(\mathrm{~d},{ }^{1} J 64.0 \mathrm{~Hz}, i-\mathrm{PC}_{6} \mathrm{H}_{5}\right), 96.3(\mathrm{~s}, \mathrm{SCH}), 31.8\left(\mathrm{~s}, \mathrm{NCH}_{3}\right), 14.9$ (s, $\left.\mathrm{NCCH}_{3}\right) .{ }^{31} \mathrm{P}$ NMR $\left(\mathrm{CD}_{2} \mathrm{Cl}_{2}\right): \delta_{\mathrm{P}} 31.0$ (s). $\mathrm{m} / z$ (FAB-MS) 720 $\left(18, \mathrm{Au}\left(\mathrm{PPh}_{3}\right)_{2}{ }^{+}\right), 587\left(71,\left(\mathrm{M}-\mathrm{NO}_{3}\right)^{+}\right), 459\left(82, \mathrm{AuPPh}_{3}{ }^{+}\right)$.

Preparation of 1,3-dimethyl-1,3-dihydro-benzimidazol-2ylideneamine-(1,3-di-tert-butylimidazol-2-ylidine)gold(I) nitrate, 7. A solution of $\left[\mathrm{Au}\left(\mathrm{NO}_{3}\right)\left(1,3-{ }^{\mathrm{t}} \mathrm{BuIm}-2\right.\right.$-ylidene $\left.)\right](0.17 \mathrm{~g}, 0.39 \mathrm{mmol})$ in THF $(10 \mathrm{ml})$ was added to a stirring solution of $\mathbf{I}(0.06 \mathrm{~g}, 0.39$ $\mathrm{mmol})$ in THF (20 ml). Upon addition a white suspension formed. The mixture was allowed to stir overnight at room temperature. The brownish solution was stripped of solvent in vacuo and the remaining residue was extracted with $\mathrm{CH}_{2} \mathrm{Cl}_{2}$, filtered through $\mathrm{MgSO}_{4}$ and reduced to dryness to yield the product as an off-white solid $(0.23 \mathrm{~g}, 96 \%)$. Mp 127-132 (decomp. ${ }^{\circ} \mathrm{C}$. Found: $\mathrm{C}, 40.2 ; \mathrm{H}, 5.4 ; \mathrm{N}, 13.9 . \mathrm{C}_{20} \mathrm{H}_{31} \mathrm{AuN}_{6} \mathrm{O}_{3}$ requires $\mathrm{C}, 40.0 ; \mathrm{H}$, $5.2 ; \mathrm{N}, 14.0 \% . v_{\max } / \mathrm{cm}^{-1} 3193 \mathrm{w} v(\mathrm{~N}-\mathrm{H}), 2966 \mathrm{~m} v\left(\mathrm{C}_{\text {aryl }}-\mathrm{H}\right)$, $1628 \mathrm{~s} v(\mathrm{C}=\mathrm{N}), 1499 \mathrm{~m} v\left(\mathrm{C}=\mathrm{C}_{\text {aryl }}\right), 733 \mathrm{~m} v(\mathrm{C}=\mathrm{C}) .{ }^{1} \mathrm{H}$ NMR $\left(\mathrm{CD}_{2} \mathrm{Cl}_{2}\right): \delta_{\mathrm{H}} 7.21(2 \mathrm{H}, 2, \mathrm{NCH}), 7.20\left(2 \mathrm{H}, \mathrm{dd},{ }^{3} J 5.8 \mathrm{~Hz},{ }^{4} J\right.$ $3.2 \mathrm{~Hz}, \mathrm{NCCHCH}), 7.11\left(2 \mathrm{H}, \mathrm{dd},{ }^{3} J 5.9 \mathrm{~Hz},{ }^{4} J 3.2 \mathrm{~Hz}, \mathrm{NCCH}\right)$, $3.79\left(6 \mathrm{H}, \mathrm{s}, \mathrm{NCH}_{3}\right), 2.18(1 \mathrm{H}, \mathrm{bs}, \mathrm{NH}), 1.89\left(18 \mathrm{H}, \mathrm{s}, \mathrm{NCCH}_{3}\right)$. ${ }^{13} \mathrm{C}$ NMR $\left(\mathrm{CD}_{2} \mathrm{Cl}_{2}\right): \delta_{\mathrm{C}} 165.6(\mathrm{~s}, \mathrm{AuC}), 156.2(\mathrm{~s}, \mathrm{NCN}), 131.3$ (s, NCCH), $122.8(\mathrm{~s}, \mathrm{NCCHCH}), 117.4(\mathrm{~s}, \mathrm{NCH}), 108.5$ (s, $\mathrm{NCCH}), 59.3\left(\mathrm{NCCH}_{3}\right), 31.9\left(\mathrm{~s}, \mathrm{NCCH}_{3}\right), 29.7\left(\mathrm{~s}, \mathrm{NCH}_{3}\right) . \mathrm{m} / z$ (FAB-MS) $\left.557\left(69,\left[\mathrm{Au}\left({ }^{(} \mathrm{Bu}_{2} \mathrm{Im}\right)_{2}\right]^{+}\right), 538\left(22,\left(\mathrm{M}-\mathrm{NO}_{3}\right)^{+}\right]\right), 524(5$, $\left.\left(\mathrm{M}-\mathrm{NO}_{3}-\mathrm{CH}_{3}\right)^{+}\right), 377\left(15,\left[\mathrm{Au}\left({ }^{+} \mathrm{Bu}_{2} \mathrm{Im}\right)_{2}\right]-\left({ }^{(} \mathrm{Bu}\right)^{+}\right)$.

\section{Anti-cancer assays}

Cytotoxicity assays were performed to establish the sensitivity of HeLa cells to the compounds I-III and 4-7, at varying concentrations, using cervical carcinoma cells (HeLa; ATCC CCL2) maintained in EMEM (Sigma Aldrich, St. Louis, MO, USA) supplemented with $10 \%$ heat inactivated fetal calf serum (Sigma Aldrich, St. Louis, MO, USA) and 1\% penicillin-streptomycin (BioWhittaker, Walkersville, Maryland). $20 \mathrm{mM}$ stock solutions of experimental compounds were prepared in DMSO. $5 \times 10^{2}$ cells/well were exposed to different concentrations $(0.5-50 \mu \mathrm{M})$ of the complexes in 96-well tissue culture plates and incubated in a $5 \% \mathrm{CO}_{2}$ incubator for 7 days at $37^{\circ} \mathrm{C}$. Drug-free solvent controls were included. The $\mathrm{IC}_{50}$ data for cisplatin were determined under the same conditions. A metabolic assay based on the reactivity of MTT (3-(4,5-dimethylthiazol-2-yl)-2,5-diphenyl-tetrazolium bromide), originally described by Mosmann ${ }^{36}$ with modifications by van Rensburg et al. ${ }^{37}$ was used to determine the effects of the experimental compounds on cell growth.

Dose-response assays were performed to derive $\mathrm{IC}_{50}$ values against resting and phytohaemagglutinin(PHA)-stimulated human lymphocytes in order to determine whether cytotoxicity observed against HeLa cells may not be tumour specific. The final concentration of PHA that was added to the relevant wells was $5 \mu \mathrm{g} \mathrm{ml}^{-1}$. Heparinised human blood, obtained from healthy volunteers, was used to prepare the cell suspensions using Histopaque-1077 (Sigma Aldrich, St. Louis, MO, USA) as described by Smit et al..$^{38}$ The cells were maintained in RPMI medium supplemented with $10 \%$ fetal calf serum and were seeded at $2 \times 10^{5}$ per well and incubated for 3 days in the presence of varying concentrations of the experimental compounds as described above. The MTT assay was used to determine cell survival after treatment.

\section{Antimalarial activity}

Plasmodium falciparum (3D7 strain) parasites were routinely cultured in a medium consisting of RPMI-1640, supplemented with $50 \mathrm{mM}$ glucose, $25 \mathrm{mM}$ HEPES, $0.65 \mathrm{mM}$ hypoxanthine, $0.2 \%(\mathrm{w} / \mathrm{v}) \mathrm{NaHCO}_{3}, 0.5 \%$ (w/v) Albumax II and $0.048 \mathrm{mg}$ $\mathrm{mL}^{-1}$ gentamicin. The medium was further supplemented with $2-$ $4 \%$ human erythrocytes (type $\mathrm{O}+$ ) and cultures were maintained in sealed tissue culture flasks suffused with $3 \% \mathrm{CO}_{2}, 4 \% \mathrm{O}_{2}$, balance $\mathrm{N}_{2}$. Parasite life-cycle stages were regularly synchronised by incubating infected erythrocytes in 5\% sorbitol for $5 \mathrm{~min}$, followed by sedimentation and resuspension in culture medium. For antimalarial activity determinations, cultures containing parasites in predominantly the early to mid-trophozoite stage were used. Infected erythrocytes were mixed with fresh culture medium and uninfected erythrocytes to obtain a $2 \%$ parasitaemia, $2 \%$ haematocrit suspension, which was distributed in microtitre plates at a volume of $100 \mu \mathrm{L}$ per well. Three-fold serial dilutions of test compounds were prepared in culture medium in a separate plate and $100 \mu \mathrm{L}$ per well transferred to the plate containing the parasite cultures. Four wells contained infected erythrocytes in medium with compound solvent alone (max. $0.5 \% \mathrm{v} / \mathrm{v}$; viability control) and four additional wells contained uninfected erythrocytes (background control). The microtitre plates were sealed in containers with an atmosphere of $3 \% \mathrm{CO}_{2}, 4 \% \mathrm{O}_{2}$, balance $\mathrm{N}_{2}$ and incubated for $48 \mathrm{~h}$ at $37^{\circ} \mathrm{C}$. Percentage parasite viability in test wells relative to the viability controls was determined by a colorimetric assay for parasite lactate dehydrogenase. ${ }^{39} \mathrm{The}^{\mathrm{IC}_{50}}$ for each test compound was calculated from dose-response plots of $\%$ parasite viability $v s . \log ($ compound concentration), using the non-linear regression function of GraphPad Prism software. Each compound concentration was assayed in duplicate wells, and $\mathrm{IC}_{50}$ determinations were carried out on three separate occasions. Assessment of haemolytic activity was done in parallel plates containing compound serial dilutions incubated for $48 \mathrm{~h}$ with uninfected erythrocytes in culture medium. An aliquot of the supernatant was removed and absorbance at $405 \mathrm{~nm}$ measured as an indication of haemolysis relative to haemolytic controls consisting of wells treated with $0.2 \%(\mathrm{w} / \mathrm{v})$ saponin.

\section{X-ray crystal structure determinations}

Crystal data collection and refinement details of compounds I, III, IV, 1-3, 4b, 5, $\mathbf{6 b}$ and $\mathbf{7}$ are summarised in Table 3 and 4. Data sets were collected on a Bruker SMART Apex CCD diffractometer with graphite monochromated Mo-K $\alpha$ radiation $(\lambda=0.71073 \AA) .{ }^{40}$ Data reduction was performed according to standard methods using the software package Bruker SAINT and data were treated with SADABS. ${ }^{41-43}$ All the structures were solved using direct methods or interpretation of a Patterson synthesis, which yielded the position of the metal atoms, and conventional difference Fourier methods. All non-hydrogen atoms were refined anisotropically by full-matrix least squares calculations on $\mathrm{F}^{2}$ using SHELX-9 $97^{44}$ within an X-seed environment. ${ }^{45}$ All hydrogen atoms, except the imine hydrogen atoms of compounds $7, \mathbf{6 b}$ and ligand $\mathbf{I}$ and hydrogen atoms on the water molecules in 6b and I were fixed in calculated positions. The disordered $\mathrm{CF}_{3} \mathrm{SO}_{3}{ }^{-}$counterion of $\mathbf{6} \mathbf{b}$ was modelled in two orientations $(58: 42)$. Figures were generated with X-seed and POV Ray for 
Table 3 Crystallographic and data collection parameters of I, III, IV, $\mathbf{1}$ and $\mathbf{2}^{a}$

\begin{tabular}{|c|c|c|c|c|c|}
\hline Compound reference & $\mathbf{I}$ & III & IV & 1 & 2 \\
\hline Chemical formula & $\mathrm{C}_{9} \mathrm{H}_{17} \mathrm{~N}_{3} \mathrm{O}_{3}$ & $\mathrm{C}_{5} \mathrm{H}_{8} \mathrm{~N}_{2} \mathrm{~S}$ & $\mathrm{C}_{35} \mathrm{H}_{30} \mathrm{~F}_{6} \mathrm{~N}_{6} \mathrm{O}_{6} \mathrm{~S}_{6}$ & $\mathrm{C}_{15} \mathrm{H}_{11} \mathrm{AuF}_{5} \mathrm{~N}_{3}$ & $\mathrm{C}_{18} \mathrm{H}_{16} \mathrm{AuF}_{5} \mathrm{~N}_{2} \mathrm{OS}$ \\
\hline Formula mass & 215.26 & 128.19 & 1007.91 & 525.23 & 600.35 \\
\hline$a / \AA$ & $11.348(3)$ & $6.949(1)$ & $14.381(2)$ & $13.684(2)$ & $9.309(2)$ \\
\hline$b / \AA ̊$ & $12.090(4)$ & $13.498(3)$ & $13.755(2)$ & $13.522(2)$ & $9.355(2)$ \\
\hline$c / \AA$ & $8.619(3)$ & $14.301(3)$ & $20.620(3)$ & $16.365(2)$ & $11.773(3)$ \\
\hline$\alpha\left(^{\circ}\right)$ & 90.00 & $108.286(3)$ & 90.00 & 90.00 & $99.080(3)$ \\
\hline Unit cell volume $/ \AA^{3}$ & $1170.7(6)$ & $1242.9(4)$ & $4036.2(10)$ & 2883.9(7) & $917.0(3)$ \\
\hline$T / \mathrm{K}$ & $100(2)$ & $100(2)$ & $100(2)$ & $100(2)$ & $100(2)$ \\
\hline Space group & $P 2_{1} / c$ & $P \overline{1}$ & $P 2_{1} / c$ & $P 2_{1} / c$ & $P \overline{1}$ \\
\hline No. of formula units per unit cell, $Z$ & 4 & 8 & 4 & 8 & 2 \\
\hline No. of reflections measured & 6351 & 6852 & 20878 & 15450 & 9785 \\
\hline No. of independent reflections & 2400 & 4625 & 7476 & 5763 & 3994 \\
\hline Goodness of fit on $F^{2}$ & 1.110 & 0.880 & 1.046 & 1.071 & 1.071 \\
\hline
\end{tabular}

Table 4 Crystallographic and data collection parameters of $3,4 \mathbf{b}, 5,6 \mathbf{b}$ and $7^{a}$

\begin{tabular}{|c|c|c|c|c|c|}
\hline Compound reference & 3 & $4 b$ & 5 & $6 \mathbf{b}$ & 7 \\
\hline Chemical formula & $\mathrm{C}_{14} \mathrm{H}_{14} \mathrm{AuF}_{5} \mathrm{~N}_{2} \mathrm{OS}$ & $\mathrm{C}_{27} \mathrm{H}_{26} \mathrm{AuN}_{4} \mathrm{O}_{3} \mathrm{P}$ & $\mathrm{C}_{26} \mathrm{H}_{23} \mathrm{AuN}_{3} \mathrm{O}_{3} \mathrm{PS}$ & $\mathrm{C}_{72} \mathrm{H}_{71} \mathrm{Au}_{3} \mathrm{~F}_{9} \mathrm{~N}_{6} \mathrm{O}_{10} \mathrm{P}_{3} \mathrm{~S}_{6}$ & $\mathrm{C}_{41} \mathrm{H}_{64} \mathrm{Au}_{2} \mathrm{Cl} 2 \mathrm{~N}_{12} \mathrm{O}_{6}$ \\
\hline Formula mass & 550.30 & 682.45 & 685.48 & 2227.52 & 1285.88 \\
\hline$a / \AA$ & $6.776(1)$ & $9.322(2)$ & $8.1497(7)$ & $35.318(5)$ & $9.109(1)$ \\
\hline$b / \AA$ & 17.691(4) & $15.499(3)$ & $9.462(1)$ & $35.318(5)$ & $10.968(2)$ \\
\hline$c / \AA$ & $15.393(3)$ & $17.446(3)$ & $17.913(2)$ & $11.178(2)$ & $12.293(2)$ \\
\hline$\alpha\left(^{\circ}\right)$ & 90.00 & 90.00 & $86.292(2)$ & 90 & $86.931(2)$ \\
\hline Unit cell volume $/ \AA^{3}$ & $1682.6(6)$ & $2502.7(8)$ & $1227.9(2)$ & $12075(3)$ & $1211.6(3)$ \\
\hline$T / \mathrm{K}$ & $100(2)$ & $100(2)$ & $100(2)$ & $100(2)$ & $100(2)$ \\
\hline Space group & $P 2_{1} / c$ & $P 2_{1} / c$ & $P \overline{1}$ & $\mathrm{R} \overline{3}$ & $P \overline{1}$ \\
\hline No. of formula units per unit cell, $Z$ & 4 & 4 & 2 & 2 & 1 \\
\hline No. of reflections measured & 9242 & 13604 & 11163 & 22365 & 12702 \\
\hline No. of independent reflections & 3191 & 4946 & 4614 & 5126 & 4929 \\
\hline Goodness of fit & 0.972 & 1.081 & 1.036 & 1.032 & 1.114 \\
\hline
\end{tabular}

Windows, with the displacement ellipsoids at 50\% probability level.

\section{Acknowledgements}

We thank the NRF (National Research Foundation of South Africa), CANSA (the Cancer Association of South Africa) and the Alexander Von Humboldt Foundation (HGR and SC) for financial support.

\section{References}

1 (a) K. Denicke and A. Greiner, Angew. Chem., Int. Ed., 2003, 42, 1340 1354; (b) K. Denicke, M. Krieger and W. Massa, Coord. Chem. Rev., 1999, 182, 19-65.

2 K. Dehnicke and F. Weller, Coord. Chem. Rev., 1997, 158, 103-169.

3 M. Tamm, S. Randoll, T. Bannenberg and E. Herdtweck, Chem. Commun., 2004, 876-877.

4 (a) P. Morain, C. Abrahams, B. Portevin and G. De Nanteuil, Mol. Pharmacol., 1994, 46, 732-742; (b) C. R. Sirtori and C. Pasik, Pharmacol. Res., 1994, 30, 187-228; (c) G. Anfossi, I. Russo, K. Bonomo and M. Trovati, Curr. Vasc. Pharmacol., 2010, 8, 327-337; 
(d) N. Papanas and E. Maltezos, Clinical Medicine: Therapeutics, 2009, 1, 1367-1381; (e) D. Sweeney, M. L. Raymer and T. D. Lockwood, Biochem. Pharmacol., 2003, 66, 663-677.

5 (a) A. Boirea, M. C. Dubroecq, A. Imperato, P. Jimonet, S. Mignani and J. Randle, PCT Int. Appl., 1997, 13pp; (b) J. Sterling, L. Hayardeny, E. Falb, Y. Herzig and D. Lerner, U.S. Pat. Appl. Publ., 2004, 25pp; (c) J. Ramnauth, N. Bhardwaj, R. Suman and S. Maddaford, PCT Int. Appl., 2004, 74pp.

6 (a) P. W. Bowyer, R. S. Gunaratne, M. Grainger, C. Withers-Martinez, S. R. Wickramsinghe, E. W. Tate, R. J. Leatherbarrow, K. A. Brown, A. A. Holder and D. F. Smith, Biochem. J., 2007, 408, 173-180; (b) I. A. Kaye and I. M. Roberts, J. Am. Chem. Soc., 1951, 73, 4762-4764.

7 D. Fan, C. T. Yang, J. D. Randford and J. J. Vittal, Dalton Trans., 2003, 4749-4753.

8 E. R. T. Tiekink, Gold Bull., 2003, 36, 117-124.

9 (a) S. P. Fricker, in The chemistry of organic derivatives of gold and silver, ed. S. Patai and Z. Rappoport, John Wiley \& Sons, Chichester, 1999, p. 655; (b) C. F. Shaw III, Chem. Rev., 1999, 99, 2589-2600.

10 S. Berners-Price, P. J. Sadler, in Bioinorganic Chemistry, ed. M. J. Clarke, J. B. Goodenough, J. A. Ibers, C. K. Jørgenen, D. M. P. Mingos, J. B. Neilands, G. A. Palmer, D. Reinen, P. J. Sadler, R. Weiss and R. J. P. Williams, Springer-Verlag, Heidelberg, 1988, p. 38.

11 P. J. Barnard, M. V. Baker, S. J. Berners-Price, B. W. Skelton and A. H. White, Dalton Trans., 2004, 1038-1047.

12 W. Schneider, A. Bauer, A. Schier and H. Schmidbaur, Chem. Ber, 1997, 130, 1417-1428.

13 N. Kuhn, R. Fawzi, M. Steimann, J. Wiethoff, D. Bläser and R. Boese, Z. Naturforsch., 1995, 50b, 1779-1784.

14 T. Deligeorgiev and N. I. Gadjev, Dyes Pigm., 1995, 29, 315322.

15 J. Coetzee, W. F. Gabrielli, K. Coetzee, O. Schuster, S. D. Nogai, S. Cronje and H. G. Raubenheimer, Angew. Chem., Int. Ed., 2007, 46, 2497-2500.

16 S. Cronje, H. G. Raubenheimer, H. S. C. Spies, C. Esterhuysen, H. Schmidbaur, A. Schier and G. J. Kruger, Dalton Trans., 2003, 28592866.

17 L. Malatesta, L. Naldini, G. Simonetta and F. Cariati, Coord. Chem. Rev., 1966, 1, 255-262.

18 M. V. Baker, P. J. Barnard, S. K. Brayshaw, J. L. Hickey and B. W. Skelton, Dalton Trans., 2005, 37-43.

19 H. Schottenberger, K. Wurst, U. E. I. Horvath, S. Cronje, J. Lukasser, J. Polin, J. M. McKenzie and H. G. Raubenheimer, Dalton Trans., 2003, 4275-4281.

20 (a) J-L. Thomas, J. Howarth, K. Hanlon and D. McGuirk, Tetrahedron Lett., 2000, 41, 413-416; (b) J. Howarth, J-L. Thomas, K. Hanlon and D. McGuirk, Synth. Commun., 2000, 30, 1865-1878.

21 R. F. Fenske, in Organometallic Compounds, Synthesis, Structure and Theory, ed. B. L. Shapiro, Texas A \& M University Press, Texas, 1983, p. 305.
22 H. G. Raubenheimer and S. Cronje, Dalton Trans., 2008, 1265-1272.

23 A. Marchi, L. Marvelli, M. Cattabriga, R. Rossi, M. Neves, V. Bertolasi and V. Ferretti, J. Chem. Soc., Dalton Trans., 1999, 1937-1944.

24 J. C. Wang, M. N. I. Khan and J. P. Fackler Jr., Acta Crystallogr., Sect. C: Cryst. Struct. Commun., 1989, 45, 1008-1010.

25 A. Codina, E. J. Fernández, P. G. Jones, A. Laguna, J. M. López-deLuzuriaga, M. Monge, M. E. Olmos, J. Pérez and M. A. Rodriguez, J. Am. Chem. Soc., 2002, 124, 6781-6786.

26 (a) J. E. Aquado, M. J. Calhorda, M. Concepción Gimeno and A. Laguna, Chem. Commun., 2005, 3355-3356; (b) W. F. Gabrielli, PhD Thesis, University of Stellenbosch, 2005, ch. 3.

27 V. J. Catalano and A. L. Moore, Inorg. Chem., 2005, 44, 6558-6566.

28 (a) M. C. Guineno and A. Laguna, in Comprehensive Coordination Chemistry II, ed. J. A. McCleverty and T. J. Meyer, Elsevier, Amsterdam, 2003, vol. 6, p. 1056.

29 H. Schmidbaur, W. Graf, W. Müller and G. Müller, Angew. Chem., Int. Ed. Engl., 1988, 27, 417-419.

30 R. Usón, A. Laguna and M. Laguna, Inorg. Synth., 1989, 26, 85-87.

31 R. Usòn and A. Laguna, in Organometallic Synthesis, ed. R. B. Lang and J. J. Eisch, Elsevier, Amsterdam, 1986, vol. 3, pp. 324-325.

32 M. I. Bruce, B. K. Nicholson and O. Bin Shawkataly, Inorg. Synth., 1989, 26, 324-326.

33 A. Haas, J. Helmbrecht and U. Nieman, in Handbuch der Präparativen Anorganichen Chemie, ed. G. Brauer, Ferdinand Enke, Stuttgart, 3rd edn, 1978, vol. 2, p. 1014.

34 (a) W. A. Hermann, V. P. W. Bohm, C. W. K. Gstottmayr, M. Grosche, C. P. Reisinger and T. Weskamp, J. Organomet. Chem., 2001, 617-618, 616-628; (b) W. A. Hermann, L. J. Goossen, C. Koecher and G. R. J. Artus, Angew. Chem., Int. Ed. Engl., 1996, 35, 2805-2807.

35 H. H. Murray and J. P. Fackler, Jr., Inorg. Chim. Acta, 1986, 115, $207-$ 209

36 T. Mosmann, J. Immunol. Methods, 1983, 65, 55-63.

37 C. E. J. van Rensburg, R. Anderson, G. Joone, M. S. Myer and J. F. O'Sullivan, Anti-Cancer Drugs, 1997, 8, 708-713.

38 T. Smit, J. R. Snyman, E. W. Neuse, L. Bohm and C. E. J. van Rensburg, Anti-Cancer Drugs, 2005, 16, 501-506.

39 M. T. Makler and D. J. Hinrichs, Am. J. Trop. Med. Hyg., 1993, 48, 205-210.

40 SMART Data Collection Software (version 5.629), Bruker AXS Inc. (Madison), WI, 2003.

41 SAINT, Data Reduction Software (version 6.45), Bruker AXS Inc. (Madison), WI, 2003.

42 R. H. Blessing, Acta Crystallogr., Sect. A: Found. Crystallogr., 1995, 51, 33-38.

43 SADABS (version 2.05), G. M. Sheldrick, University of Göttingen, Germany, 1997.

44 G. M. Sheldrick, Acta Crystallogr., Sect. A: Found. Crystallogr., 2008, 64, 112-122.

45 L. J. Barbour, J. Supramol. Chem., 2003, 1, 189-191. 